\title{
Use of the SWB-Sci Model for Nitrogen Management in Sludge-
}

\section{Amended Land}

Eyob H. Tesfamariam ${ }^{\mathrm{a}, *}$, John G. Annandale ${ }^{\mathrm{a}}$, Joachim M. Steyn ${ }^{\mathrm{a}}$, Richard J. Stirzaker ${ }^{\text {a, b }}$, Ikenna Mbakwe $^{\mathrm{a}}$

a Department of Plant Production and Soil Science, University of Pretoria, Private bag x20, Hatfield, 0028, Pretoria

${ }^{\mathrm{b} C S I R O ~ L a n d ~ a n d ~ W a t e r, ~ P O ~ B o x ~ 1666, ~ A C T ~ 2601, ~ A u s t r a l i a ~ a n d ~ C R C ~ f o r ~ I r r i g a t i o n ~ F u t u r e s, ~ P O ~}$ Box 56, Darling Heights, Queensland, Australia 4350

*Corresponding author Tel: +27 12420 4724; Fax: +27 12420 4120;

E-mail:eyob.tesfamariam@up.ac.za

\begin{abstract}
Process-based computer simulation models are often used as reasoning support tools to integrate the complex processes involved in the soil-plant-atmosphere system. The objectives of this study were to evaluate the performance of the SWB-Sci model as a reasoning support tool for sludge management in agricultural lands, and use the validated model to assess the long-term agronomic and environmental implications of water availability and crop intensity on sludge-amended land. The model was calibrated for the test crops, maize (Zea mays Pan6966) and oats (Avena sativa L.), using data collected during the 2004/05 growing season from irrigated plots at the East Rand Water Care
\end{abstract}


Works, Gauteng, South Africa. Model validation was performed using independent data sets collected during the 2004/05 to 2007/08 growing seasons. The model was successfully calibrated for maize and oats as all the statistical parameters were within the prescribed ranges [index of agreement $(d)>0.8$; relative mean absolute error $(\mathrm{MAE} \%)<20 \%$; coefficient of determination $\left.\left(\mathrm{r}^{2}\right)>0.8\right]$. The results indicate that SWB-Sci simulated aboveground biomass (TDM) and grain yield (GY) of maize and oats with high accuracy $\left(\mathrm{d}>0.85\right.$, MAE\% $\leq 20 \%$, and $\left.\mathrm{r}^{2}>0.91\right)$ but with a slight overestimation by $0.2-4 \mathrm{Mg} \mathrm{ha}^{-1}$. The model predicted nitrate leaching and crop $\mathrm{N}$ uptake reasonably well $(\mathrm{d}>0.85$, MAE $\% \leq 14 \%$, and $\mathrm{r}^{2}>0.8$ ), with slight overestimation of TDM and GY N uptake by $11-57$ and 4 - $48 \mathrm{~kg} \mathrm{ha}^{-1}$, respectively. Long-term model simulations indicate that fixed sludge application rate recommendations generated from laboratory incubation studies may in the long-term result in spontaneous excessive nitrate leaching below the active root zone during high rainfall events, if recommendations do not consider $\mathrm{N}$ contribution from soil organic matter. Modelling also showed that leaving room for rain during each irrigation event may minimize the risk of nitrate leaching.

Keywords: nitrogen; modelling; irrigation; nitrate leaching; maize; oats; farming intensity

\section{Introduction}

Sludge use in agriculture has become attractive because it presents a double-barrelled solution to improving soil fertility and reducing waste accumulation at wastewater treatment plants. Sludge has been shown to improve the physical and chemical properties of soil and aid crop production (Boyle and Paul, 1989; Seleiman et al., 2012; Du et al., 2012). In order to ensure that constituent elements in sludge do not become a risk to the environment, sludge is screened for its agricultural suitability, and limits to how much sludge can be applied to agronomic land are set by regulatory bodies. In South Africa, a limit of 10 tons sludge per hectare per year has been set by the Water Research Commission (Snyman and Herselman, 2006). 
Sludge is a major contributor of nitrogen; however, a large fraction of the nitrogen in sewage sludge is in organic form (Tesfamariam, 2009) and must first be transformed to inorganic nitrogen forms before the nitrogen can be available for crop uptake (Kelley et al., 1984). All major processes involved in the nitrogen cycle of agricultural lands, including crop nutrient uptake, are influenced by water availability, soil temperature, climatic factors, soil type, management practices, crop type, and farming intensity (Tesfamariam, 2009). In addition, the processes involved in the transformation of organic $\mathrm{N}$ into inorganic $\mathrm{N}$ are influenced by factors such as organic matter composition (Janssen, 1996), soil texture (Garau et al., 1986), soil water, and soil temperature (Leiros et al., 1999; Guntiñas et al., 2012)).

The complex interaction between the different factors involved in the nitrogen cycle of the soil - plant system (Heimann and Reichstein, 2008) makes it difficult to extrapolate field studies across different agro-climatic conditions and soil types (Kropff et al., 2001). Ideally, specific studies would need to be conducted across various agro-ecological zones, soil types, sludge types, cropping systems, and management practices (Tesfamariam, 2009). This is not only expensive but also logistically impractical. A validated mechanistic model can, however, play a significant role in extrapolating results by conducting scenario simulations for various types of crops grown on various soil types and under different climatic conditions (Kropff et al., 2001).

Modelling the dynamics of nitrogen in the soil system dates back to the early 1970s (Shaffer et al., 2001). The first integrated soil system N models were built in the USA (Dutt et al., 1972) and in the Netherlands (Beek and Frissel, 1973). Nitrogen models vary from purely research-oriented to management and screening-oriented tools (Shaffer et al., 2001). The level of complexity of the Page $\mathbf{3}$ of $\mathbf{3 8}$ 
various processes included in these models differs considerably, from simple empirically based formulations to sophisticated mechanistic approaches (Bergström et al., 1991).

In this study, the SWB-Sci model was selected because the water balance and crop growth modules of the model have already been intensively validated for various field crops, vegetables and grasses under irrigation (Jovanovic et al., 1999, Beletse et al., 2008) and dryland (Jovanovic et al., 2002) conditions in South Africa. The SWB-Sci model is a mechanistic Soil-Water balance (Annandale et al., 1996), crop growth/ irrigation scheduling (Annandale et al., 2000, 2003), $\mathrm{N}$ and $\mathrm{P}$ balance (Tesfamariam, 2009; van der Laan, 2010) model. The recently added N cycle sub-routine of the SWB model was adopted from the Cropping Systems Simulation Model (CropSyst) (Stöckle et al., 2003). This newly added $\mathrm{N}$ subroutine has not yet been tested for its reliability to simulate $\mathrm{N}$ dynamics in sludge amended agricultural lands. The aims of this study were: a) to test the reliability of the newly added N subroutine of the SWB-Sci model in sludge-amended soils using independent data sets, b) to use the validated model to assess the long-term agronomic and environmental implication of water availability and cropping intensity on sludge-amended land.

\section{Materials and methods}

This study required an $\mathrm{N}$ model that could simulate various scenarios including dryland and irrigated systems with a range of management practices, the reason being that $\mathrm{N}$ management, salt management and irrigation are inextricably linked. There is also a need to explore trade-offs between nutrient management, optimal yields and pollution such as through nitrate leaching in sludge amended agricultural lands. In order to test the reliability of the SWB-Sci model, a field experiment was conducted on two cropping systems (dryland maize and irrigated maize-oat rotation) using four sludge application rates. 


\subsection{Study site description}

Field experiments were conducted at the East Rand Water Care Works (ERWAT), Johannesburg, Gauteng, South Africa. The study site is situated at an elevation of $1577 \mathrm{~m}$ above sea level, latitude $26^{\circ} 01^{\prime} 01^{\prime \prime} \mathrm{S}$ and longitude of $28^{\circ} 16^{\prime} 55^{\prime \prime} \mathrm{E}$. The total annual rainfall of the area ranged between $405 \mathrm{~mm}$ in 2006/07 and $710 \mathrm{~mm}$ in 2007/08, mainly during the months of October to March. The soil of the experimental site is a clay loam, Hutton soil form (Soil Classification Working Group, 1991) having an average clay content of $38 \%$, and $\mathrm{pH}\left(\mathrm{H}_{2} \mathrm{O}\right)$ of 5.73 .

\subsection{Sludge characteristics}

The sludge used was anaerobically digested, dried in concrete beds and was collected from Vlakplaas, East Rand Water Care Works, Johannesburg, Gauteng, South Africa. According to the current South African sludge guideline (Snyman and Herselman, 2006), this sludge can be used safely as a fertilizer in agricultural lands as long as the $\mathrm{N}$ applied does not exceed crop demand, with the upper limit set at $10 \mathrm{Mg} \mathrm{ha}^{-1} \mathrm{yr}^{-1}$. Selected properties of the sludge used are presented in Table 1.

Table 1 Selected properties of sludge used during the 2004/05 - 2007/08 growing seasons

\begin{tabular}{cccccc}
\hline & & \multicolumn{5}{c}{ Year } \\
\cline { 3 - 6 } Parameter measured & Unit & $2004 / 05$ & $2005 / 06$ & $2006 / 07$ & $2007 / 08$ \\
\hline $\mathrm{N}$ & $\%$ & 3.032 & 1.884 & 2.219 & 3.094 \\
$\mathrm{NH}_{4} \_\mathrm{N}$ & $\mathrm{mg} \cdot \mathrm{kg}^{-1}$ & 2018 & 4362 & 4064 & 7660 \\
$\mathrm{NO}_{3 \_} \mathrm{N}$ & $\mathrm{mg} \cdot \mathrm{kg}^{-1}$ & 183 & 6 & 40 & 11 \\
\hline
\end{tabular}




\begin{tabular}{cccccc}
\hline $\mathrm{P}$ & $\%$ & 1.962 & 1.844 & 2.76 & 2.24 \\
Total C & $\%$ & 23 & 20 & 21 & 20 \\
$\mathrm{~K}$ & $\mathrm{mg} \cdot \mathrm{kg}^{-1}$ & 3804 & 710 & 689 & 1356 \\
$\mathrm{Ca}$ & $\mathrm{mg} \cdot \mathrm{kg}^{-1}$ & 25116 & 13062 & 17450 & 10042 \\
$\mathrm{Mg}$ & $\mathrm{mg} \cdot \mathrm{kg}^{-1}$ & 5358 & 591 & 829 & 1145 \\
$\mathrm{Cd}$ & $\mathrm{mg} \cdot \mathrm{kg}^{-1}$ & 1.63 & 0.07 & 0.15 & 18.91 \\
$\mathrm{Hg}$ & $\mathrm{mg} \cdot \mathrm{kg}^{-1}$ & 1.70 & 0.02 & 0.03 & 1.81 \\
$\mathrm{Cr}$ & $\mathrm{mg} \cdot \mathrm{kg}^{-1}$ & 51.93 & 1.50 & 2.92 & 503.8 \\
$\mathrm{As}$ & $\mathrm{mg} \cdot \mathrm{kg}^{-1}$ & 7.08 & 0.18 & 0.23 & 17.94 \\
$\mathrm{~Pb}$ & $\mathrm{mg} \cdot \mathrm{kg}^{-1}$ & 54.46 & 9.41 & 1.37 & 102.0 \\
$\mathrm{Zn}$ & $\mathrm{mg} \cdot \mathrm{kg}^{-1}$ & 459.9 & 4.33 & 20.85 & 2325 \\
$\mathrm{Ni}$ & $\mathrm{mg} \cdot \mathrm{kg}^{-1}$ & 23.81 & 1.37 & 0.97 & 144.5 \\
$\mathrm{Cu}$ & $\mathrm{mg} \cdot \mathrm{kg}^{-1}$ & 97.2 & 3.21 & 4.59 & 526.8 \\
\hline
\end{tabular}

\subsection{Experimental layout}

Field plots of $25 \mathrm{~m}^{2}$ were arranged in a randomized complete block design comprising four replications of four sludge treatments and two cropping systems (dry land maize and irrigated maizeoat rotation). The sludge treatments consisted of 3 application rates $\left(4,8\right.$, and $\left.16 \mathrm{Mg} \mathrm{ha}^{-1} \mathrm{yr}^{-1}\right)$ and an unamended zero control. The trial was laid out to accommodate widely different levels of bio-solid applications. All treatments, except the zero control, were supplemented with commercial $\mathrm{K}$ fertilizer (dryland maize $60 \mathrm{~kg} \mathrm{ha}^{-1}$, irrigated maize $100 \mathrm{~kg} \mathrm{ha}^{-1}$, and oats $86 \mathrm{~kg} \mathrm{ha}^{-1}$ ) because municipal sludge is a poor source of $\mathrm{K}(\sim 0.3 \%)$. For the irrigated maize-oats rotation, the annual sludge application rate was split into two, with half applied at planting time of maize and the remaining half at the plating time of oats. For dryland maize, however, the full annual rate was applied at planting time. The sludge was spread uniformly and incorporated immediately into the top $0.2-0.3 \mathrm{~m}$ soil layer with a manually operated, diesel powered rotovator (Agria) and the plots were levelled using rakes. After levelling, 
maize (Zea mays L. PAN 6966) was planted in $0.9 \mathrm{~m}$ rows at rates of 80000 seeds per hectare under irrigation and half this rate under dryland. Each plot consisted of 6 rows of $5 \mathrm{~m}$ in length, with one border on either side. In winter, oats (Avena sativa L.) were planted at a rate of $90 \mathrm{~kg} \mathrm{ha}^{-1}$ (270 plants $\mathrm{m}^{-2}$ ) using a hand-drawn planter with double disk openers. Each oats plot consisted of 15 rows, spaced $0.3 \mathrm{~m}$ apart and $5 \mathrm{~m}$ in length, with two border rows on either side.

\subsection{Irrigation and rainfall}

The irrigated maize-oats rotation experiment was planted under drip irrigation. The dripper lines were pressure compensated, having a flow rate of $1.3 \mathrm{~L} \mathrm{~h}^{-1}$ at a working pressure range of 100 to $150 \mathrm{kPa}$. The lateral spacing between dripper lines was $0.3 \mathrm{~m}$ and the spacing between drippers within a line was $0.3 \mathrm{~m}$. In the absence of rainfall, maize was irrigated $10 \mathrm{~mm}$ every three days for the first four weeks after planting. In 2005, this was followed by irrigation according to the FAO crop factor method (Allen et al., 1998) in the SWB model once every five days until harvest in the absence of rainfall. In 2007 and 2008, however, maize was irrigated on a weekly basis according to a site-specific calibrated neutron water meter (Model 503 DR CPN Hydroprobe; Campbell Pacific Nuclear, CA) profile deficit readings to bring soil water content back to field capacity. During the winter season, oats were irrigated every three days (9 mm in 2005 and $10 \mathrm{~mm}$ in 2007 and 2008) for the first four weeks after planting. This was followed by irrigations according to a site-specific calibrated neutron water meter deficit readings, mostly twice a week in 2005 , which was modified to a weekly bases in 2006 and 2008 because of the low weekly water use observed in 2005 . The neutron water meter readings for both crops were collected to a depth of $1.2 \mathrm{~m}$. During the growing season, however, plant water extraction by maize extended to a depth of $1.1 \mathrm{~m}$, while for oats it did not go deeper than $0.6 \mathrm{~m}$. Total irrigation water applied for each crop is presented in Table 2. Weather data was collected from an automatic weather station located $100 \mathrm{~m}$ from the study site. Two-weekly mean temperature and rainfall data recorded during the study period are presented in Table 3. 
Table 2 Annual irrigation application for each sludge treatment of the irrigated maize-oat rotation during the 2004/05 to 2008/09 growing seasons, ERWAT, Ekurhuleni district Pretoria, South Africa.

\begin{tabular}{lccccc}
\hline $\begin{array}{l}\text { Sludge } \\
\text { application }\end{array}$ & \multicolumn{5}{c}{ Maize } \\
\cline { 2 - 6 } rate $\left(\mathrm{t} \mathrm{ha}^{-1}\right)$ & $2004 / 05$ & $2006 / 07$ & $2007 / 08$ & $2005 / 06$ & $2006 / 07$ \\
\cline { 2 - 6 } & 463 & 539 & 350 & 509 & 531 \\
\hline 0 & 463 & 541 & 374 & 552 & 594 \\
\hline 4 & 463 & 550 & 393 & 569 & 600 \\
8 & 463 & 577 & 424 & 590 & 630 \\
\hline
\end{tabular}

\subsection{Soil solution sampling for nitrate analyses}

Nitrate leaching was monitored by wetting front detectors (WFDs; www.fullstop.com.au) installed both at 0.3 and $0.6 \mathrm{~m}$ depths and located in the middle of each experimental plot of all treatments. The WFD is a funnelshaped instrument that converges the downward flow of water in the soil, producing saturation when the surrounding soil reaches 2 to $3 \mathrm{kPa}$ suction (Stirzaker, 2003; Stirzaker and Hutchinson, 2005). It is essentially a passive lysimeter that signals the passing of a wetting front and stores a soil water sample as the front passes (Tesfamariam et al., 2009). Soil solution samples collected from the wetting front detectors were then analyzed for nitrate concentration using a C99 Multiparameter Bench Photometer (Hanna Instruments, Italy). 
Table 3 Two-weekly mean maximum and minimum temperature, mean average temperature, and two-weekly cumulative precipitation during the 2004/05 to 2008/09 growing seasons, ERWAT, Ekurhuleni district Pretoria, South Africa.

\begin{tabular}{|c|c|c|c|c|c|c|c|c|c|c|c|c|c|c|c|c|c|c|c|c|c|}
\hline \multirow{3}{*}{$\begin{array}{l}\text { Period } \\
\text { Month }\end{array}$} & \multirow[b]{3}{*}{ Weeks } & \multicolumn{4}{|c|}{2004} & \multicolumn{4}{|c|}{2005} & \multicolumn{4}{|c|}{2006} & \multicolumn{4}{|c|}{2007} & \multicolumn{4}{|c|}{2008} \\
\hline & & \multicolumn{3}{|c|}{$\begin{array}{l}\text { Temperature } \\
\left({ }^{\circ} \mathrm{C}\right)\end{array}$} & \multirow{2}{*}{$\begin{array}{l}\text { Rain } \\
\mathrm{mm} \\
\end{array}$} & \multicolumn{3}{|c|}{$\begin{array}{l}\text { Temperature } \\
\left({ }^{\circ} \mathrm{C}\right)\end{array}$} & \multirow{2}{*}{$\begin{array}{l}\text { Rain } \\
\mathrm{mm}\end{array}$} & \multicolumn{3}{|c|}{$\begin{array}{l}\text { Temperature } \\
\left({ }^{\circ} \mathrm{C}\right)\end{array}$} & \multirow{2}{*}{$\begin{array}{l}\text { Rain } \\
\mathrm{mm}\end{array}$} & \multicolumn{3}{|c|}{$\begin{array}{l}\text { Temperature } \\
\left({ }^{\circ} \mathrm{C}\right)\end{array}$} & \multirow{2}{*}{$\begin{array}{l}\text { Rain } \\
\mathrm{mm} \\
\end{array}$} & \multicolumn{3}{|c|}{$\begin{array}{l}\text { Temperature } \\
\left({ }^{\circ} \mathrm{C}\right)\end{array}$} & \multirow{2}{*}{$\begin{array}{l}\text { Rain } \\
\mathrm{mm}\end{array}$} \\
\hline & & $\max$ & $\min$ & ave & & $\max$ & $\min$ & ave & & $\max$ & $\min$ & ave & & $\max$ & $\min$ & ave & & $\max$ & $\min$ & ave & \\
\hline \multirow[t]{2}{*}{ Jan. } & $1-2$ & & & & & 29 & 16 & 23 & 111 & 26 & 17 & 21 & 51 & 29 & 13 & 21 & 47 & 24 & 15 & 20 & 59 \\
\hline & $3-4$ & & & & & 26 & 16 & 21 & 56 & 26 & 15 & 21 & 57 & 29 & 14 & 21 & 24 & 23 & 14 & 18 & 148 \\
\hline \multirow[t]{2}{*}{ Feb. } & $1-2$ & & & & & 29 & 16 & 22 & 17 & 26 & 15 & 20 & 103 & 30 & 13 & 21 & 30 & 25 & 14 & 19 & 56 \\
\hline & $3-4$ & & & & & 27 & 15 & 21 & 79 & 27 & 15 & 21 & 70 & 32 & 14 & 23 & 0 & 27 & 15 & 21 & 5 \\
\hline \multirow[t]{2}{*}{ Mar. } & $1-2$ & & & & & 27 & 12 & 20 & 27 & 24 & 12 & 18 & 13 & 30 & 13 & 22 & 6 & 24 & 14 & 19 & 117 \\
\hline & $3-4$ & & & & & 25 & 12 & 18 & 44 & 23 & 12 & 18 & 38 & 27 & 11 & 19 & 7 & 22 & 11 & 16 & 42 \\
\hline \multirow[t]{2}{*}{ Apr. } & $1-2$ & & & & & 23 & 11 & 17 & 45 & 24 & 9 & 17 & 10 & 26 & 10 & 18 & 0 & 24 & 11 & 18 & 17 \\
\hline & $3-4$ & & & & & 22 & 8 & 15 & 18 & 21 & 8 & 14 & 9 & 21 & 8 & 15 & 19 & 24 & 10 & 17 & 0 \\
\hline \multirow[t]{2}{*}{ May } & $1-2$ & & & & & 23 & 5 & 14 & 1 & 21 & 5 & 13 & 0 & 21 & 5 & 13 & 0 & 22 & 10 & 16 & 33 \\
\hline & $3-4$ & & & & & 2 & 4 & 13 & 0 & 19 & 2 & 10 & 3 & 19 & 0 & 10 & 0 & 19 & 8 & 13 & 10 \\
\hline June & $1-2$ & & & & & 22 & 3 & 12 & 0 & 22 & 3 & 12 & 0 & 18 & 3 & 10 & 29 & 17 & 6 & 12 & 14 \\
\hline \multirow[t]{2}{*}{ July } & $1-2$ & & & & & 19 & 1 & 10 & 0 & 20 & 2 & 11 & 0 & 17 & 0 & 8 & 0 & 16 & 5 & 10 & 0 \\
\hline & $3-4$ & & & & & 22 & 2 & 12 & 0 & 22 & 4 & 13 & 0 & 20 & 1 & 11 & 0 & 18 & 6 & 12 & 0 \\
\hline \multirow[t]{2}{*}{ Aug. } & $1-2$ & & & & & 22 & 4 & 13 & 0 & 20 & 3 & 11 & 10 & 21 & 2 & 11 & 0 & 20 & 7 & 14 & 0 \\
\hline & $3-4$ & & & & & 24 & 7 & 15 & 0 & 21 & 6 & 14 & 30 & 22 & 4 & 13 & 0 & 22 & 9 & 15 & 0 \\
\hline Sep. & $1-2$ & & & & & 26 & 8 & 17 & 0 & 24 & 6 & 15 & 0 & 27 & 13 & 20 & 0 & 25 & 9 & 17 & 0 \\
\hline & $3-4$ & & & & & 29 & 10 & 19 & 0 & 26 & 8 & 16 & 0 & 25 & 11 & 18 & 17 & 23 & 9 & 16 & 0 \\
\hline Oct. & $1-2$ & & & & & 28 & 10 & 19 & 0 & 28 & 12 & 20 & 0 & 21 & 10 & 16 & 85 & 26 & 12 & 19 & 0 \\
\hline & $3-4$ & & & & & 29 & 12 & 20 & 12 & 31 & 14 & 22 & 13 & 22 & 11 & 16 & 34 & 27 & 14 & 20 & 62 \\
\hline Nov. & $1-2$ & 30 & 15 & 22 & 12 & 28 & 13 & 20 & 55 & 28 & 13 & 21 & 42 & 25 & 13 & 19 & 4 & 26 & 14 & 20 & 52 \\
\hline & $3-4$ & 30 & 15 & 23 & 29 & 28 & 13 & 21 & 54 & 26 & 14 & 20 & 75 & 26 & 14 & 20 & 45 & 25 & 15 & 20 & 45 \\
\hline Dec. & $1-2$ & 28 & 16 & 22 & 72 & 26 & 14 & 20 & 35 & 30 & 15 & 22 & 13 & 23 & 13 & 18 & 68 & 27 & 15 & 21 & 59 \\
\hline & $3-4$ & 28 & 15 & 22 & 64 & 28 & 13 & 20 & 68 & 29 & 17 & 23 & 121 & 25 & 14 & 19 & 12 & 27 & 15 & 21 & 67 \\
\hline
\end{tabular}




\subsection{Plant sampling}

Whole plant (above-ground biomass) samples were collected every two weeks from all plots for growth analyses from an area of $0.45 \mathrm{~m}^{2}$ for oats and $0.5 \mathrm{~m}^{2}$ for maize during the 2004/05 growing season. In the 2006/07 and 2007/08 growing seasons, however, plant samples were collected only three times during the growing season (at the eight leaf, soft dough and physiological maturity stages). At the soft dough stage, plant samples were collected for forage yield determination from $2 \mathrm{~m}$ lengths of the three middle rows for maize and $2 \mathrm{~m}$ lengths of the six middle rows for oats. Additional plant samples were collected at the eight leaf growth stage, at the soft dough stage, and at crop maturity from all cropping systems for crop $\mathrm{N}$ and $\mathrm{P}$ uptake determinations.

\subsection{Growth analyses}

Plant samples collected for growth analyses from maize and oats were partitioned into leaves, stems, and grain. One sided leaf area was measured with an LI-3100 belt driven leaf area meter (LI-COR, Lincoln, NE, USA). Leaf area index (LAI) was computed from the measured one-sided leaf area divided by the ground sampling area. The components (leaves, stems, and grain) were then dried in a forced-air oven at $60{ }^{\circ} \mathrm{C}$ for 48 hours to determine above-ground biomass. Above-ground biomass was calculated as the sum of leaf, stem, and grain.

\subsection{Soil sampling}

Soil samples were collected at the beginning of the study, before treatment application, using an auger from the following soil depth intervals: 0-0.3 m, 0.3-0.6 m, 0.6-0.9 m, and 0.9-1.2 m layers. Additional soil samples were collected using a core sampler to determine bulk density and hydraulic characteristics of the soil. At the end of each growing season, an auger was used to collect three soil samples diagonally from each plot per treatment $(0-0.3 \mathrm{~m}, 0.3-0.6 \mathrm{~m}, 0.6-0.9 \mathrm{~m}$, and 0.9-1.2 m layers) and for both cropping systems. The three 
samples from each layer per plot were combined and mixed to make a single homogenous soil sample per layer.

\subsection{Plant and soil chemical analyses}

Total P in the sludge, soil, and plant samples as well as heavy metal contents of the sludge were determined after wet acid digestion, using an Inductively Coupled Plasma Optical Emission Spectrometer (ICP-OES) (SpectroFlame Modula; Spectro, Kleve, Germany). Plant extractable soil P was analyzed using the Bray-1 extraction method, following standard procedures (Non-affiliated Soil Analyses Work Committee, 1990). Soil and plant samples were ground to pass through a $150 \mu \mathrm{m}$ screen and analyzed for total $\mathrm{C}$ and $\mathrm{N}$ content using a Carlo Erba NA1500 C/N analyzer (Carlo Erba Strumentazione, Milan, Italy). Soil samples were extracted in 1:5 $1 \mathrm{M} \mathrm{KCl}$ and tested for ammonium and nitrate contents with the Lachat Autoanalyzer (Lachat Quick Chem Systems, Milwaukee, WI, USA).

\subsection{Model description}

The SWB model is a mechanistic crop growth and irrigation scheduling model developed from the NEWSWB model of G.S. Campbell (Washington State University, Pullman, WA, USA). It is a one-dimensional, daily time step generic model that uses soil, weather and crop units to mechanistically carry out crop growth and soil water and salt balance simulations. Details of the crop growth and irrigation scheduling modules of the SWB model can be found in Annandale et al. (1999) and Annandale et al. (2000). The N sub-module of the SWB-Sci model follows similar approaches to that of the Cropping Systems Simulation Model (CropSyst) (Stöckle et al., 2003). The nitrogen balance in SWB-Sci model includes nitrogen transport, nitrogen transformations, ammonium sorption and crop nitrogen uptake. The mineral nitrogen budget for SWB-Sci model has separate budgets for nitrate and ammonium. Inorganic nitrogen transport within the soil system is simulated using a daily time step approach followed by Corwin et al. (1991). SWB-Sci model simulates nitrogen transformation processes (net mineralization, nitrification, and denitrification) using first order kinetics and ammonium sorption is simulated using the approach presented by Stöckle and Campbell (1989), 
while symbiotic $\mathrm{N}$ fixation is based on Bouniols et al. (1991). Crop nitrogen uptake is modelled using a modified version of the Godwin and Jones (1991) approach, where crop nitrogen uptake is determined as the minimum of crop nitrogen demand and potential nitrogen uptake (Stöckle et al., 1994). A detailed description of the $\mathrm{N}$ module, including the major nitrogen transformation processes (mineralization, immobilization, nitrification, and denitrification) can be found in Stöckle et al. (2003). After inclusion of the N module the SWB model was renamed to the SWB-Sci model.

Field data collected during the 2004/05 growing season from the nutrient and water non-limiting treatment (irrigated $16 \mathrm{Mg} \mathrm{ha}^{-1}$ sludge treatment) was used to determine specific crop parameters for maize (Zea mays cv. PAN6966) and oats (Avena sativa) to calibrate the SWB-Sci model. Parameters such as specific leaf area, leaf-stem partitioning factor, thermal time requirements, maximum root depth, maximum crop height, dry matter-water ratio, radiation use efficiency, canopy extinction coefficient, stem to grain translocation, top dry matter at emergence, harvestable dry matter, and maximum grain $\mathrm{N}$ concentration were determined from field data according to procedures provided by Annandale et al. (1999). The remaining parameters were obtained from literature. The values for the above-mentioned parameters can be found in Tesfamariam (2009).

Selected measured variables (total aboveground biomass, grain yield, leaf area index, aboveground biomass $\mathrm{N}$ uptake, and grain $\mathrm{N}$ uptake) from the 2004/05 growing season were used to test model calibration accuracy, using statistical parameters proposed by De Jager (1994) as presented in Table 4. Model validation was conducted using three season's independent sets of variables collected from the $8 \mathrm{Mg} \mathrm{ha}^{-1}$ sludge treatments of both dryland maize and irrigated maize-oat rotation during the 2004/05 growing season and from the 8 and $16 \mathrm{Mg} \mathrm{ha}^{-1}$ sludge treatments of both dryland and irrigated maize-oat rotation during the 2006/07 and 2007/08 growing seasons. The upper sludge application norm of $8 \mathrm{Mg} \mathrm{ha}^{-1}$ and double the norm $\left(16 \mathrm{Mg} \mathrm{ha}^{-1}\right)$ were used to validate the SWB-Sci 
model because of the increased potential for nitrate leaching from such high rates, and also because the $\mathrm{N}$ supply from the $4 \mathrm{Mg} \mathrm{ha}^{-1}$ was too low to trigger nitrate leaching.

Table 4 Model evaluation statistical parameters with their reliability criteria (after de Jager, 1994)

\begin{tabular}{lll}
\hline $\begin{array}{l}\text { Statistical parameter } \\
\text { abbreviation }\end{array}$ & Extended meaning of abbreviation & $\begin{array}{l}\text { Reliability } \\
\text { criteria }\end{array}$ \\
\hline $\mathrm{R}^{2}$ & Coefficient of determination & $>0.8$ \\
$\mathrm{D}$ & Willmott (1982) index of agreement & $>0.8$ \\
$\mathrm{MAE}(\%)$ & $\begin{array}{l}\text { Mean absolute error expressed as a percentage of the } \\
\text { mean of the measured values }\end{array}$ & $<20$ \\
\hline
\end{tabular}

\section{Results and discussion}

\subsection{Model calibration}

The model was calibrated using data collected during the 2004/05 growing season from the $16 \mathrm{Mg}$ $\mathrm{ha}^{-1}$ irrigated maize-oat rotation treatment. Most of the simulated values for the selected variables of interest agreed closely with measured values (Fig. 1) and all the statistical parameters were within the ranges prescribed by De Jager (1994) (Table 5). Therefore, the model was calibrated successfully for both maize and oats. Maize aboveground biomass was underestimated towards the end of the season. Nevertheless, the difference between the simulated and measured values was not statistically significant and all the statistical parameters were within the ranges of acceptable accuracy as prescribed by De Jager (1994) (Table 4). Similarly, maize above-ground N uptake was underestimated towards the end of the season, most probably due to the underestimation of aboveground biomass. This was also indicated by a high RMSE (52.74 $\left.\mathrm{kg} \mathrm{N} \mathrm{ha}^{-1}\right)$. Model simulation results 
for oat LAI, aboveground biomass, grain yield, aboveground biomass $\mathrm{N}$ uptake and grain $\mathrm{N}$ uptake were also estimated with acceptable accuracy.

Table 5 Statistical parameters of SWB-Sci model calibration simulations for maize and oats leaf area index (LAI), aboveground biomass (TDM), aboveground biomass N uptake (TDM N uptake), grain (GY), and grain N uptake (GY N uptake) for data collected during the 2004/05 growing

\begin{tabular}{|c|c|c|c|c|c|}
\hline & & & \multicolumn{3}{|c|}{ MAE } \\
\hline Variable & $\mathrm{n}$ & $\mathrm{D}$ & RMSE & $(\%)$ & $\mathrm{R}^{2}$ \\
\hline \multicolumn{6}{|c|}{ Maize } \\
\hline LAI & 10 & 0.94 & 0.82 & 7.79 & 0.98 \\
\hline TDM & 10 & 0.98 & 2.18 & 7.4 & 0.99 \\
\hline TDM N uptake & 4 & 0.92 & 52.74 & 8.47 & 0.99 \\
\hline GY & 6 & 0.88 & 1.72 & 9.72 & 0.95 \\
\hline GY N uptake ${ }^{a}$ & 4 & 0.99 & 12.82 & 3.71 & 0.99 \\
\hline \multicolumn{6}{|c|}{ Oats } \\
\hline LAI & 7 & 0.92 & 0.38 & 17.06 & 0.93 \\
\hline TDM & 7 & 0.92 & 1.52 & 15.18 & 0.99 \\
\hline TDM N uptake & 4 & 0.95 & 13.19 & 6.73 & 0.98 \\
\hline GY & 3 & 0.9 & 0.77 & 17.39 & 0.95 \\
\hline
\end{tabular}

${ }^{\mathrm{a}} \mathrm{GY} N$ uptake by irrigated maize and oats for the irrigated maize-oat rotation double cropping system was combined for statistical analyses due to few data points measured for oats.

\subsection{Model validation}

The SWB-Sci model was validated using independent data sets collected from the $8 \mathrm{Mg} \mathrm{ha}^{-1}$ sludge treatments of each cropping system during 2004/05 and from the 8 and $16 \mathrm{Mg} \mathrm{ha}^{-1}$ sludge treatments of both cropping systems during the 2006/07 and 2007/08 growing seasons. Measured data from each sludge treatment of a given cropping system across years was pooled together for statistical analyses, when validating the model. Similar variables used in the model calibration (LAI, above-ground 
biomass, grain, and above-ground biomass grain $\mathrm{N}$ uptake) were used to validate model accuracy. Generally, the model predicted the variables of interest reasonably well under dryland and irrigated conditions and with different sludge application rates. 


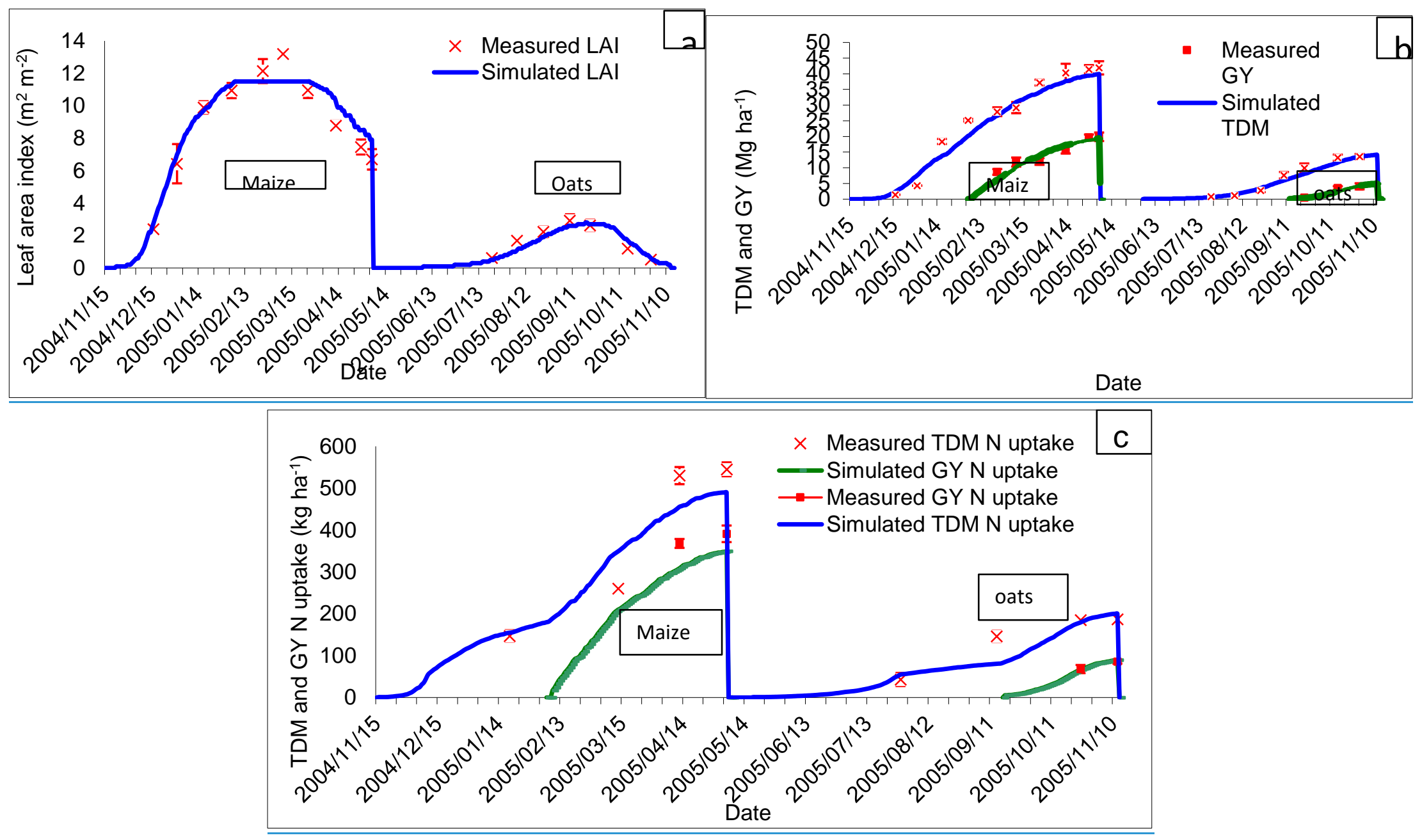

Fig.1. Simulated (solid lines) and measured values (symbols with standard deviation) for (a) maize and oats leaf area index (LAI); (b) aboveground biomass (TDM) and grain yield (GY), and (c) total aboveground biomass $N$ uptake (TDM N) and grain N uptake (GY N), planted under water and nutrient non limiting condition during the 2004/05 growing season 
Most of the statistical parameters were within the ranges of acceptable accuracy (Table 6; Figs. 2 -

4).

Table 6 Statistical parameters of SWB-Sci model corroboration for maize and oat leaf area index (LAI), aboveground biomass (TDM), aboveground biomass N uptake (TDM N uptake), grain (GY), and grain $\mathrm{N}$ uptake (GY N uptake) pooled data collected during the 2004/05 to 2007/08 growing seasons.

\begin{tabular}{lccccc}
\hline Variable & $\mathrm{n}$ & $\mathrm{d}$ & $\mathrm{RMSE}$ & $\begin{array}{l}\mathrm{MAE} \\
(\%)\end{array}$ & $\mathrm{R}^{2}$ \\
\hline \multicolumn{1}{l}{ Dryland maize $8 \mathrm{Mg} \mathrm{ha}^{-1}$} & per & annum sludge treatment \\
\hline LAI & 11 & 0.80 & 0.38 & 29 & 0.98 \\
TDM & 16 & 0.87 & 2.37 & 20 & 0.99 \\
TDM N uptake & 9 & 0.85 & 31.00 & 17 & 0.93 \\
GY & 10 & 0.87 & 1.10 & 20 & 0.91 \\
GY N uptake & 6 & 0.88 & 17.00 & 14 & 0.99 \\
\hline
\end{tabular}

Irrigated maize-oat rotation $8 \mathrm{Mg} \mathrm{ha}^{-1}$ per annum sludge treatment

\begin{tabular}{lccccc}
\hline LAI & 25 & 0.82 & 1.00 & 12.22 & 0.98 \\
TDM & 26 & 0.97 & 2.55 & 10.68 & 0.99 \\
TDM N uptake & 17 & 0.92 & 44.01 & 14.00 & 0.96 \\
GY & 17 & 0.95 & 1.17 & 7.00 & 0.98 \\
GY N uptake & 10 & 0.89 & 41.26 & 14.00 & 0.95 \\
\hline & Irrigated maize-oat rotation $16 \mathrm{Mg} \mathrm{ha}^{-1}$ per annum sludge treatment & \\
\hline LAI & 23 & 0.94 & 0.71 & 18 & 0.96 \\
TDM & 29 & 0.94 & 2.69 & 15 & 0.97 \\
TDM N uptake & 15 & 0.89 & 43.00 & 15 & 0.97 \\
GY & 18 & 0.92 & 1.59 & 16 & 0.97 \\
GY N uptake & 10 & 0.90 & 31.71 & 15 & 0.97 \\
\hline
\end{tabular}


There were, however, a few exceptions, such as the LAI, TDM, and GY of the $8 \mathrm{Mg} \mathrm{ha}^{-1}$ dryland maize treatment, where the model significantly underestimated LAI and TDM during the 2004/05 and 2007/08 growing seasons and GY during 2004/05 and 2005/06 (Fig. 2 a, b). This resulted in a slightly higher MAE (\%) value of $29 \%$ for the LAI and $20 \%$ for both TDM and GY, compared with the prescribed range of $<20 \%$. The predictive capability of the SWB-Sci model to simulate nitrate leaching was tested using linear regression by plotting nitrate leachate collected from 30 and $60 \mathrm{~cm}$ soil depths (using WFDs) against model predicted values at similar depths. The model showed reasonable accuracy in predicting leaching of nitrates in sludge-amended soil (Fig. 5) and therefore proved to be a reliable tool to investigate this phenomenon.

\subsection{Scenario Modelling for Selected Cropping Systems}

Having established the reasonable accuracy of the SWB-Sci model, scenario simulations were conducted to highlight the long-term agronomic and environmental implications of water availability and farming intensity on sludge-amended land. The following scenarios have been tested: a) rainfall/irrigation implications on sludge amended land. In this scenario the effect of water availability through rainfall and/or irrigation on crop yield, nutrient uptake as well as nitrate leaching from a clay loam soil treated with $10 \mathrm{Mg} \mathrm{ha}^{-1}$ sludge was investigated. Similarly, the effect of two irrigation strategies has been investigated (Irrigating every fifth day to fill the root zone to field capacity, irrigating every fifth day $20 \mathrm{~mm}$ less than what is needed to fill the root zone to FC leaving $20 \mathrm{~mm}$ room for rain). b) Farming intensity implications for sludge application rates. In this scenario the effect of farming intensity on annual crop production, crop nutrient utilisation and nitrate leaching per unit area from clay loam soil treated with $10 \mathrm{Mg} \mathrm{ha}^{-1}$ sludge were investigated. Historical weather data from OR Tambo international airport in Johannesburg, South Africa were used for the long-term simulations. 


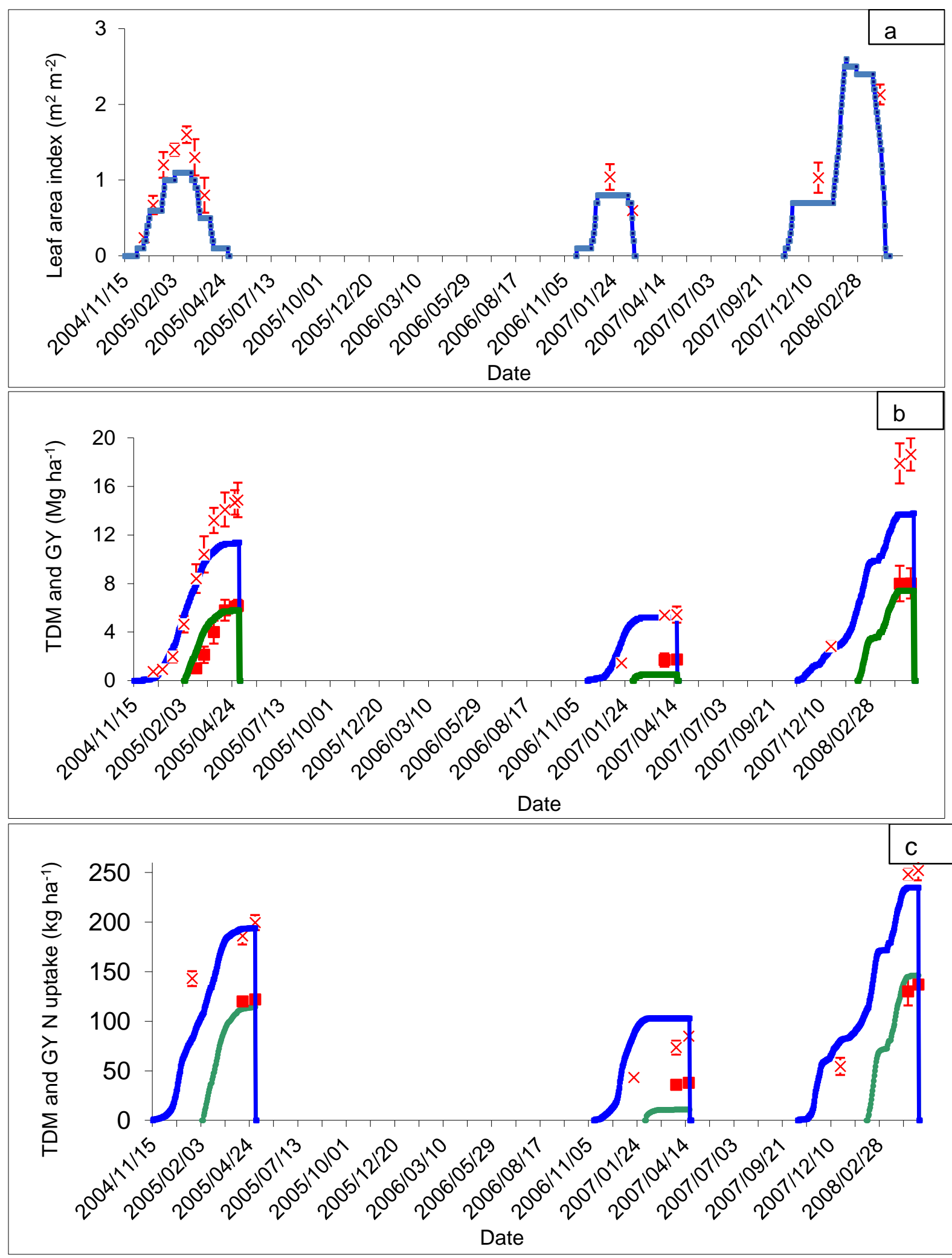

Fig.2. Simulated (solid lines) and measured values (symbols) of (a) leaf area index (LAl); (b) aboveground biomass (TDM) and grain (GY); and (c) total aboveground biomass $N$ uptake (TDM N) and grain N uptake (GY N), for the $8 \mathrm{Mg} \mathrm{ha}^{-1}$ per annum sludge-treated dryland maize during the 2004/05 to 2007/08 study period. 


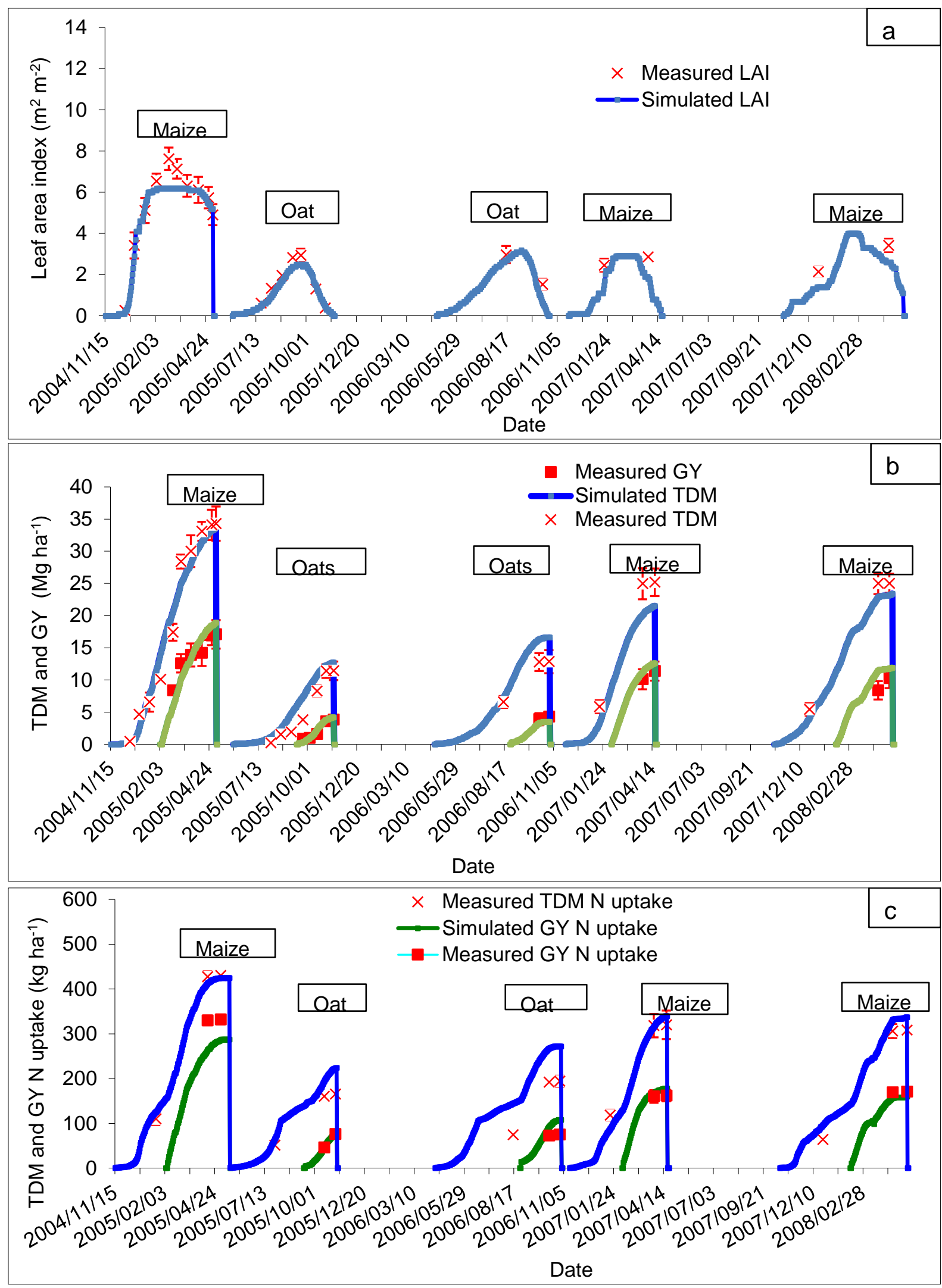

Fig.3. Simulated (solid lines) and measured values (symbols) of (a) leaf area index (LAI); (b) total aboveground biomass (TDM), and grain (GY); (c) total aboveground biomass $\mathrm{N}$ uptake (TDM N) and grain $\mathrm{N}$ uptake (GY N), for the $8 \mathrm{Mg} \mathrm{ha}^{-1}$ per annum sludge-treated irrigated maize-oat rotation during the 2004/05 to $2007 / 08$ study period. 


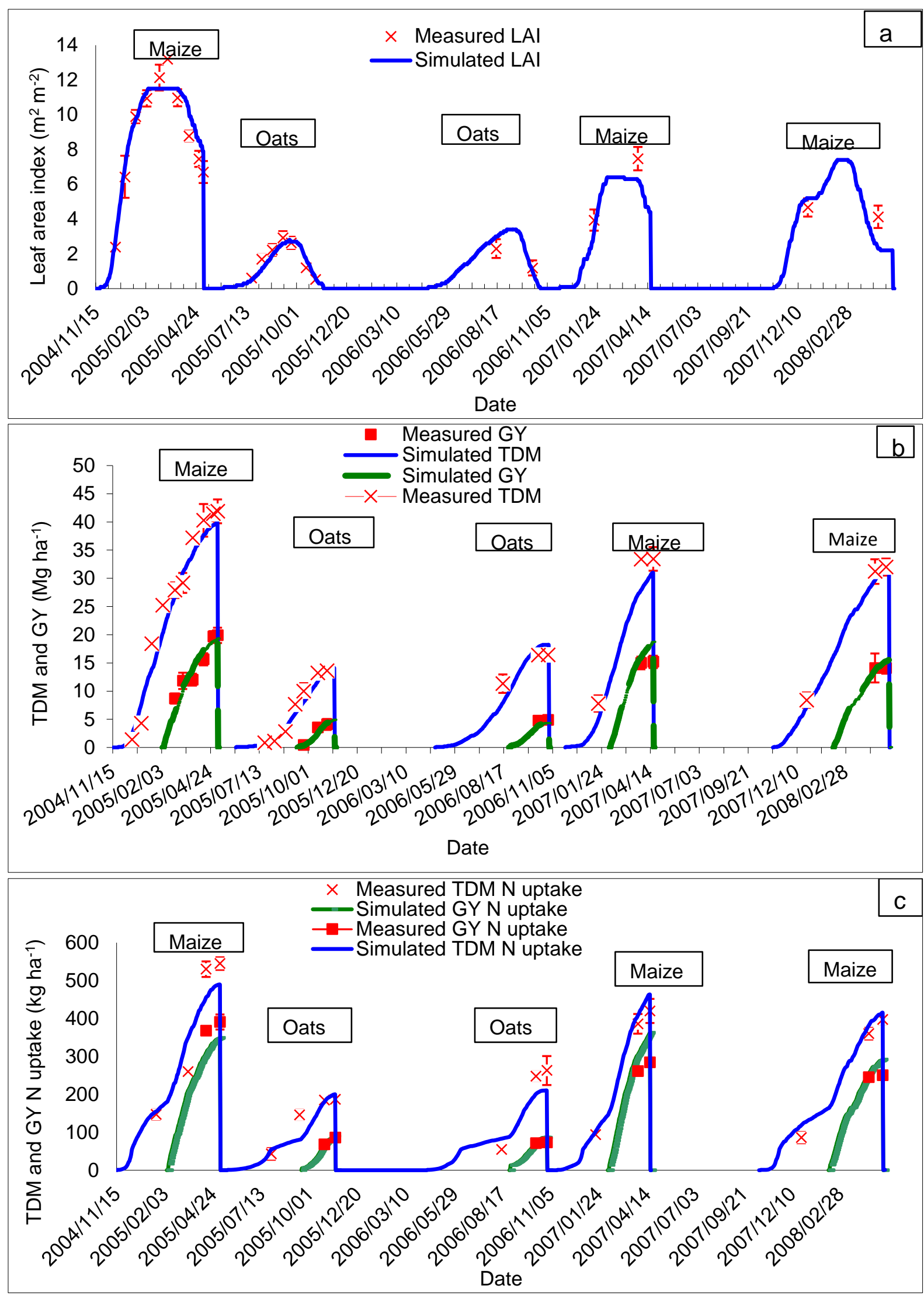

Fig.4. Simulated (solid lines) and measured values (symbols) of (a) leaf area index; (b) total aboveground biomass (TDM), and grain (GY); (c) total aboveground biomass $\mathrm{N}$ uptake and grain $\mathrm{N}$ uptake, for the $16 \mathrm{Mg}$ $\mathrm{ha}^{-1}$ per annum sludge-treated irrigated maize-oat rotation during the 2004/05 to 2007/08 study period. 


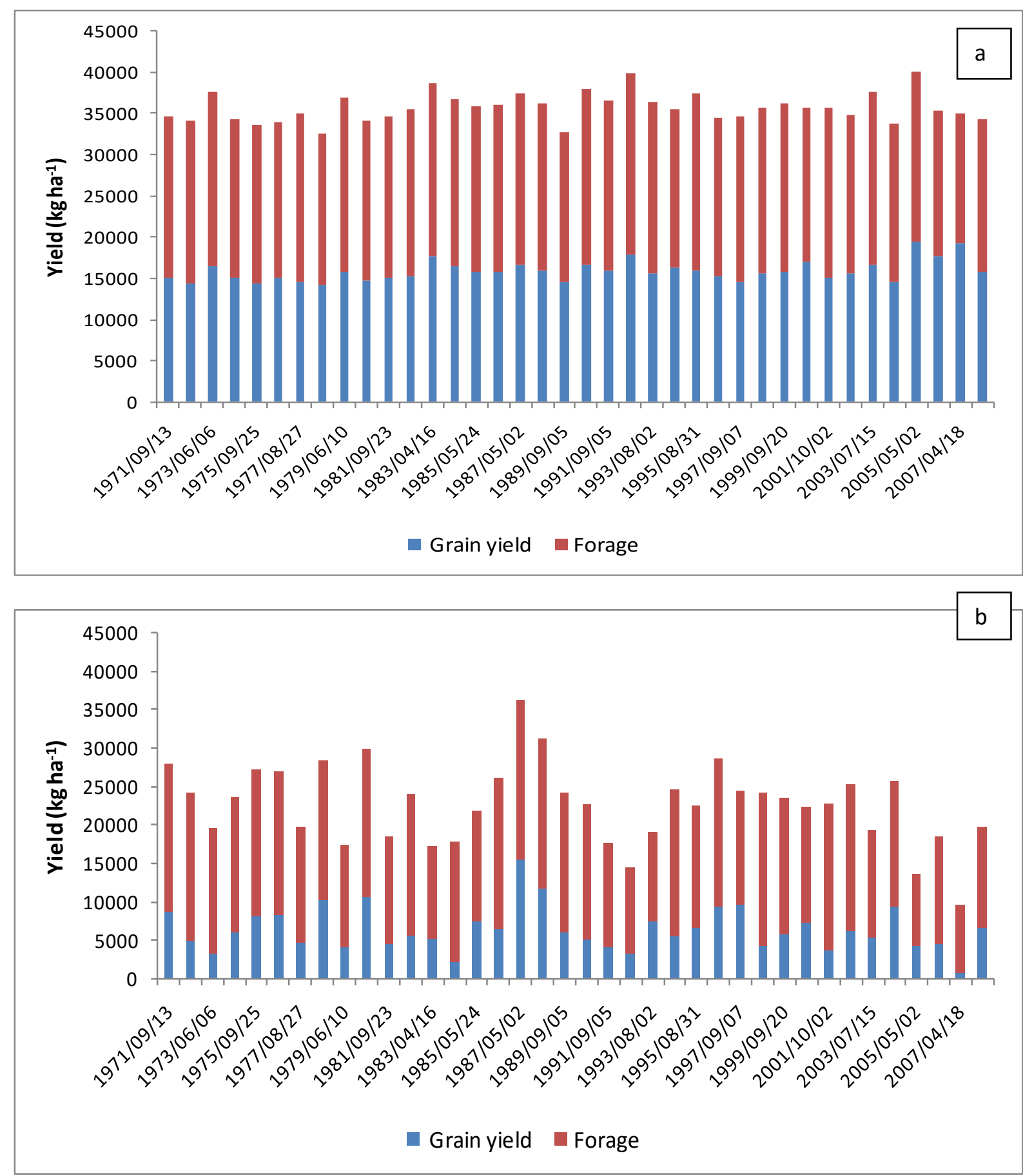

Fig. 5. Relationship between measured and SWB-Sci simulated nitrate leaching for the 8 and $16 \mathrm{Mg}$ ha-1 per annum sludge-treated irrigated maize-oat rotation during the 2004/05 and 2007/08 study period.

\subsubsection{Rainfall/irrigation implications on sludge-amended land}

In certain areas rainfall is sufficient to grow crops during most times of the year. In other areas however, prolonged dry conditions make irrigation necessary. Sludge application rates will have to 
consider whether sludge-amended land is irrigated or rainfed because nutrient release from sludge is affected by moisture conditions (Agehara and Warncke, 2005). Moreover, crop growth and nutrient uptake response to sludge application rate increases with the availability of water (Binder et al., 2002; Tesfamariam, 2009). This was also well demonstrated by model simulations of 38 years, where maize forage and grain yield was higher under irrigation than dryland farming (Fig. 6). The only exception was the wet $1986 / 87$ season, where yield was similar for both dryland and irrigated systems. It is noteworthy that crop yield under an irrigated cropping system remained consistent across years. In contrast to this, forage and grain yield of dryland maize varied across years, with the lowest yields during the 2006/07 growing season, mainly due to low rainfall (350 mm).

Generally, maize forage and grain $\mathrm{N}$ uptake was higher under irrigation than dryland farming (Fig. 7). Similarly, dryland maize $\mathrm{N}$ uptake was high during high rainfall years and low in low rainfall seasons. This was mainly attributed to the direct relationship between water availability, $\mathrm{N}$ release from sludge, and crop $\mathrm{N}$ uptake.

It is evident from the simulation graphs that it might be easier to match nutrient demand and supply of crops under irrigation than under dryland conditions. This is because there is a direct relationship between water availability, $\mathrm{N}$ release from sludge, and crop $\mathrm{N}$ uptake. Under dryland cropping systems, where rainfall is erratic, the amount of nutrients that could be utilized by a crop varies depending on the availability of rainfall. At the same time, the availability of rainfall influences the release of nutrients from organic matter. 
Although the availability of nutrients is essential for optimal crop production, amounts exceeding crop requirements and/or poor irrigation management strategies could cause severe environmental impacts through leaching or runoff (Esteller et al., 2009; Blum et al., 2013).
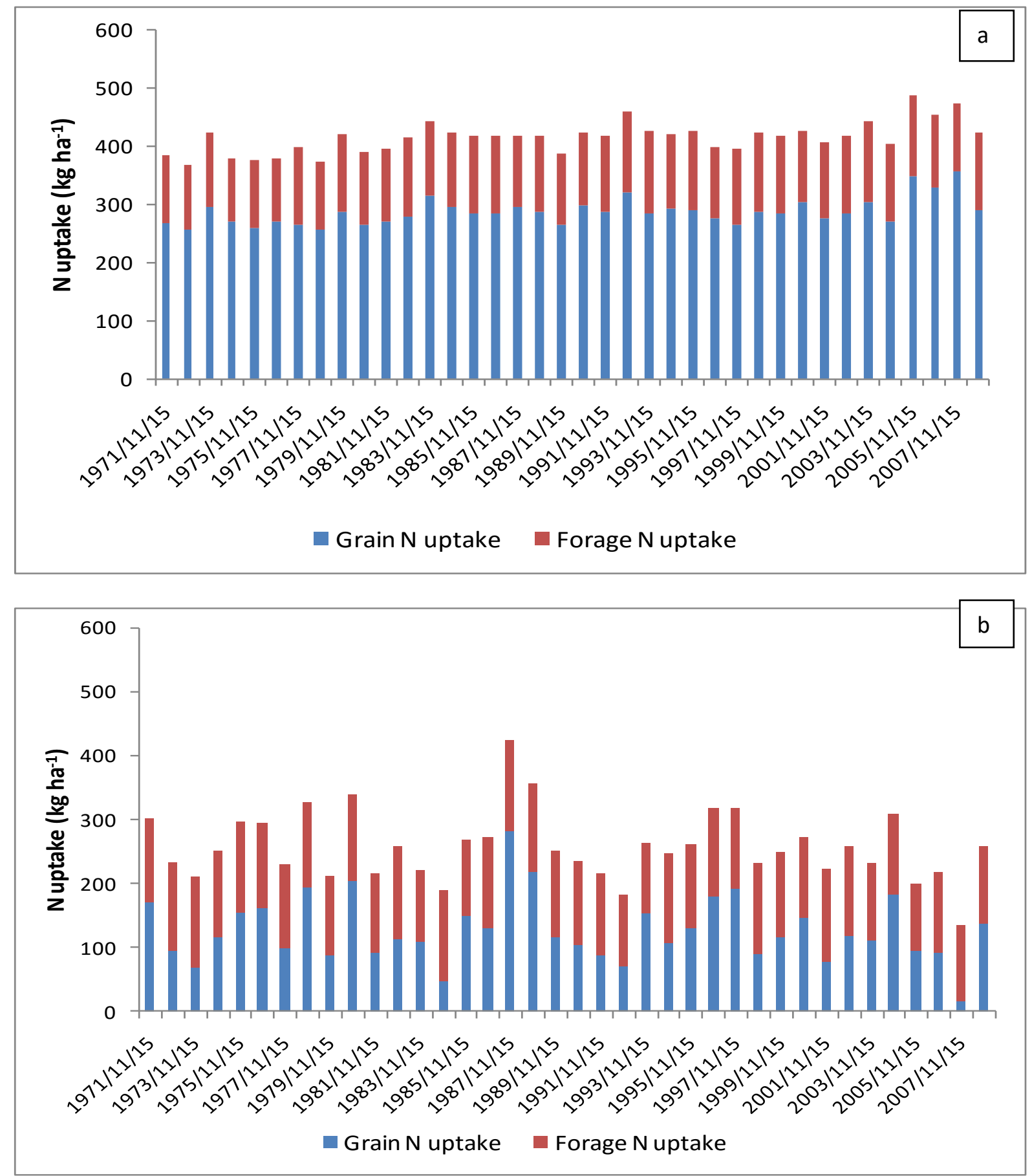

Fig.6. Simulated forage and grain yield of (a) irrigated and (b) dryland maize planted to a clay loam soil treated with $10 \mathrm{Mg} \mathrm{ha}^{-1} \mathrm{yr}^{-1}$ sludge 


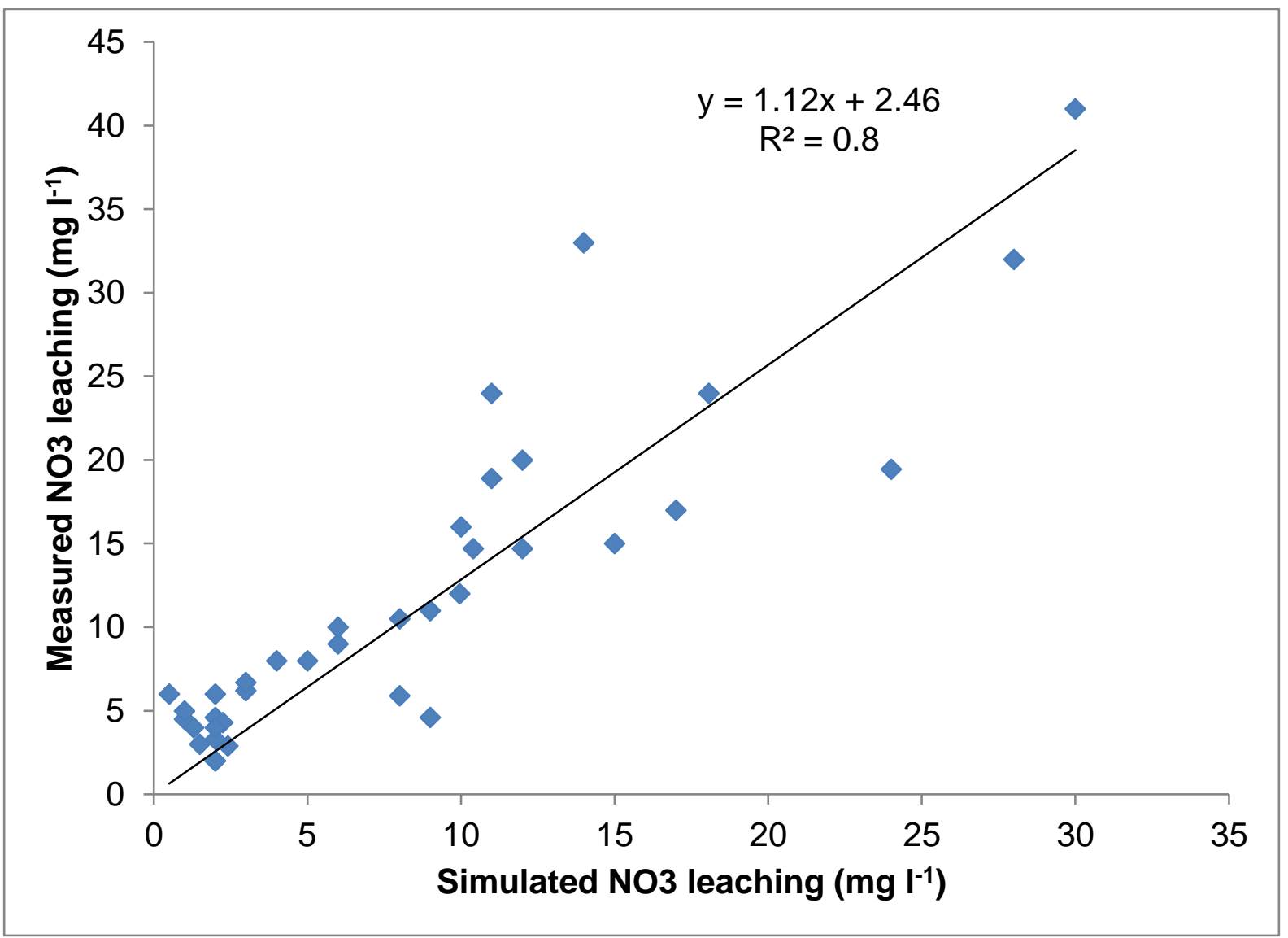

Fig.7. Simulated forage and grain $\mathrm{N}$ uptake of (a) irrigated and (b) dryland maize planted to a clay loam soil treated with $10 \mathrm{Mg} \mathrm{ha}^{-1} \mathrm{yr}^{-1}$ sludge

Simulations show that irrigating at specific intervals according to crop requirement to fill the profile to field capacity resulted in frequent but relatively low nitrate leaching from maize fields (Fig. 8a). In this specific scenario, the main cause for the nitrate leaching was rainfall events which followed after irrigation. There were also a few other instances where single high rainfall events caused leaching of nitrate below the active root zone. This is in agreement with previous findings by Arbat et al. (2013), who reported that most nitrate leaching was associated with high precipitation events that produced drainage losses and nitrate leaching from pig slurry treated irrigated maize. 

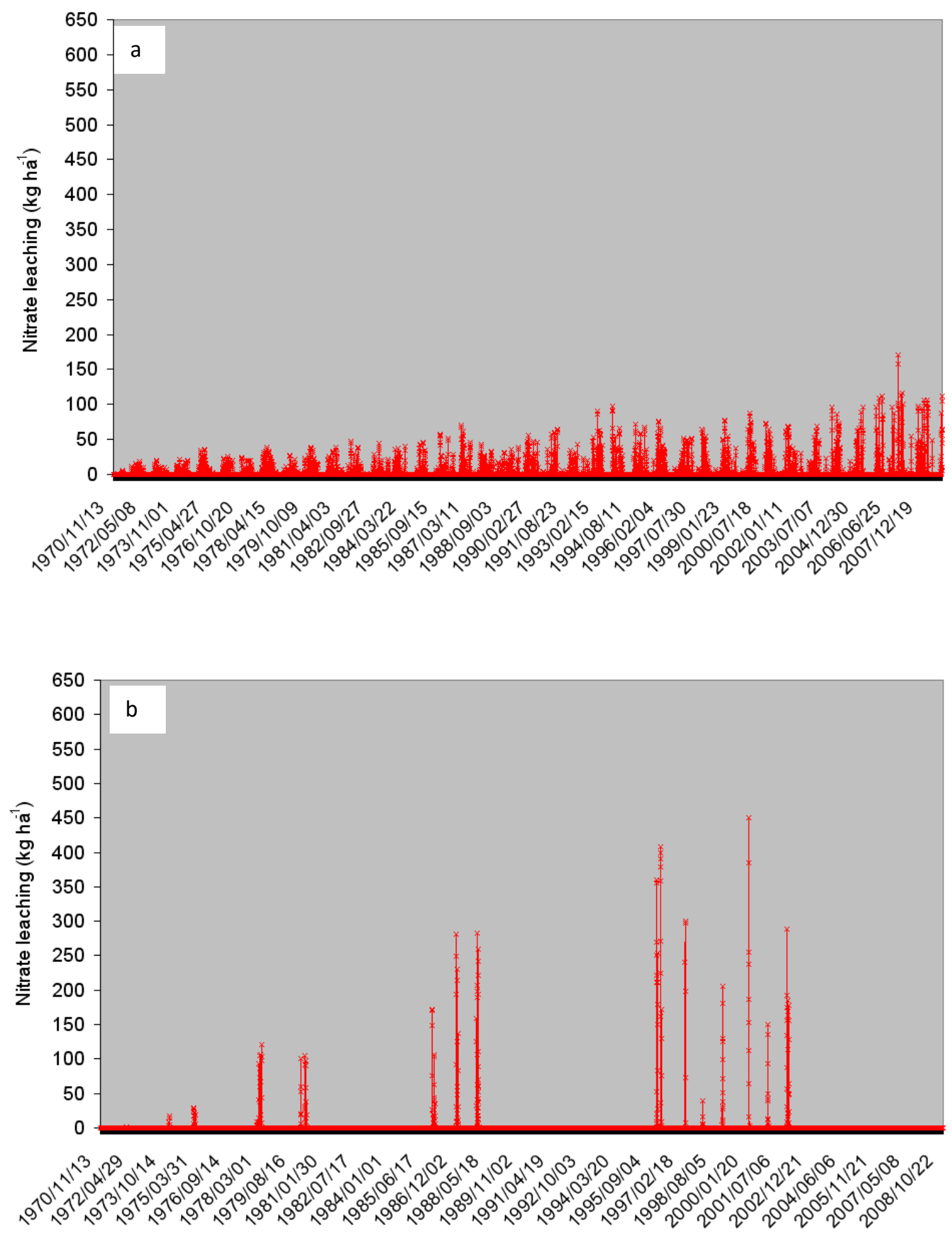

Fig.8. Simulated nitrate leaching (a) for irrigated and (b) for dryland maize planted to a clay loam soil treated with $10 \mathrm{Mg} \mathrm{ha}^{-1} \mathrm{yr}^{-1}$ sludge 
In contrast, there were very few nitrate leaching events during the same time period under dryland maize production (Fig. 8b). The $\mathrm{N}$ fluxes during those few leaching events were, however, enormous (about $400 \mathrm{~kg} \mathrm{ha}^{-1} \mathrm{~d}^{-1}$ ). Rapid flushes of nitrate following rewetting of dry soil is believed to originate from lysis of microbial cells, residual nitrate stored in soil but not taken up by plants as the soil dried out (Halverson et al., 2000; Fierer et al., 2003; Mian et al., 2008) or changes in microbial activities and diversity (Fierer et al., 2003). In addition, nitrate accumulation in the $0.9-1.5 \mathrm{~m}$ soil profile of the dryland maize increased over time, indicating a potential future environmental threat through leaching (Fig. 9b). Similar findings were reported by Yagüe and Quílez (2010) from maize trials fertilised with pig slurry in a drainage lysimeter. According to these authors, an enrichment of mineral $\mathrm{N}$ was observed in the lower layers in the following growing seasons due to the downward movement of N. The high inorganic $\mathrm{N}$ accumulation observed in the soil profile of the dryland maize is in contrast with the irrigated maize, which had relatively low nitrate accumulation throughout the profile (Fig 9a). Generally, the median value of nitrate leaching from our study under dryland maize $\left(97 \mathrm{~kg} \mathrm{ha}^{-1}\right)$ falls within the ranges reported by Yagüe and Quílez (2010) (31-241 $\mathrm{kg} \mathrm{ha}^{-1}$ ) from a sandy loam soil planted to maize that received 30,60 , and $120 \mathrm{Mg} \mathrm{ha}^{-1}$ pig slurry for four consecutive years.

The frequent nitrate leaching reported under irrigated maize could, however, be minimized through the adoption of better irrigation strategies, such as leaving room for rain during each irrigation event. SWB-Sci simulations showed that less nitrate leaching will occur when room is left for rain than when land is irrigated to field capacity, without compromising crop yield (Fig. 10). In addition, including the residual $\mathrm{NO}_{3}$ and $\mathrm{NH}_{4}$ from previous seasons stored in the root zone into $\mathrm{N}$ fertilizer management practices (Cameira et al., 2003) could also play a significant role to minimise nitrate leaching, especially at the early growth stage before full crop root development. 

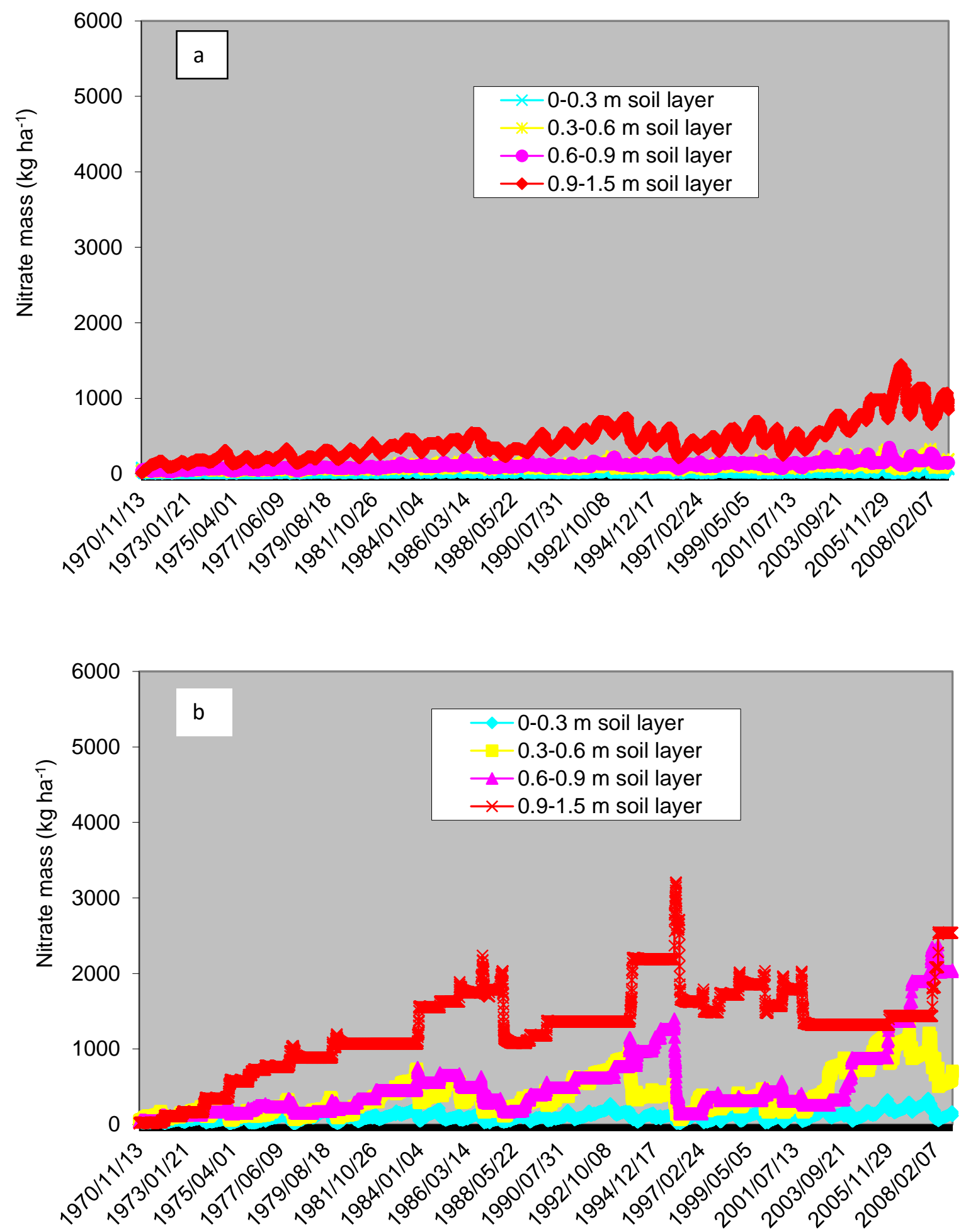

Fig.9. Simulated nitrate accumulation in the soil profile of (a) irrigated maize and (b) dryland maize planted to a clay loam soil treated with $10 \mathrm{Mg} \mathrm{ha}^{-1} \mathrm{yr}^{-1}$ sludge. 


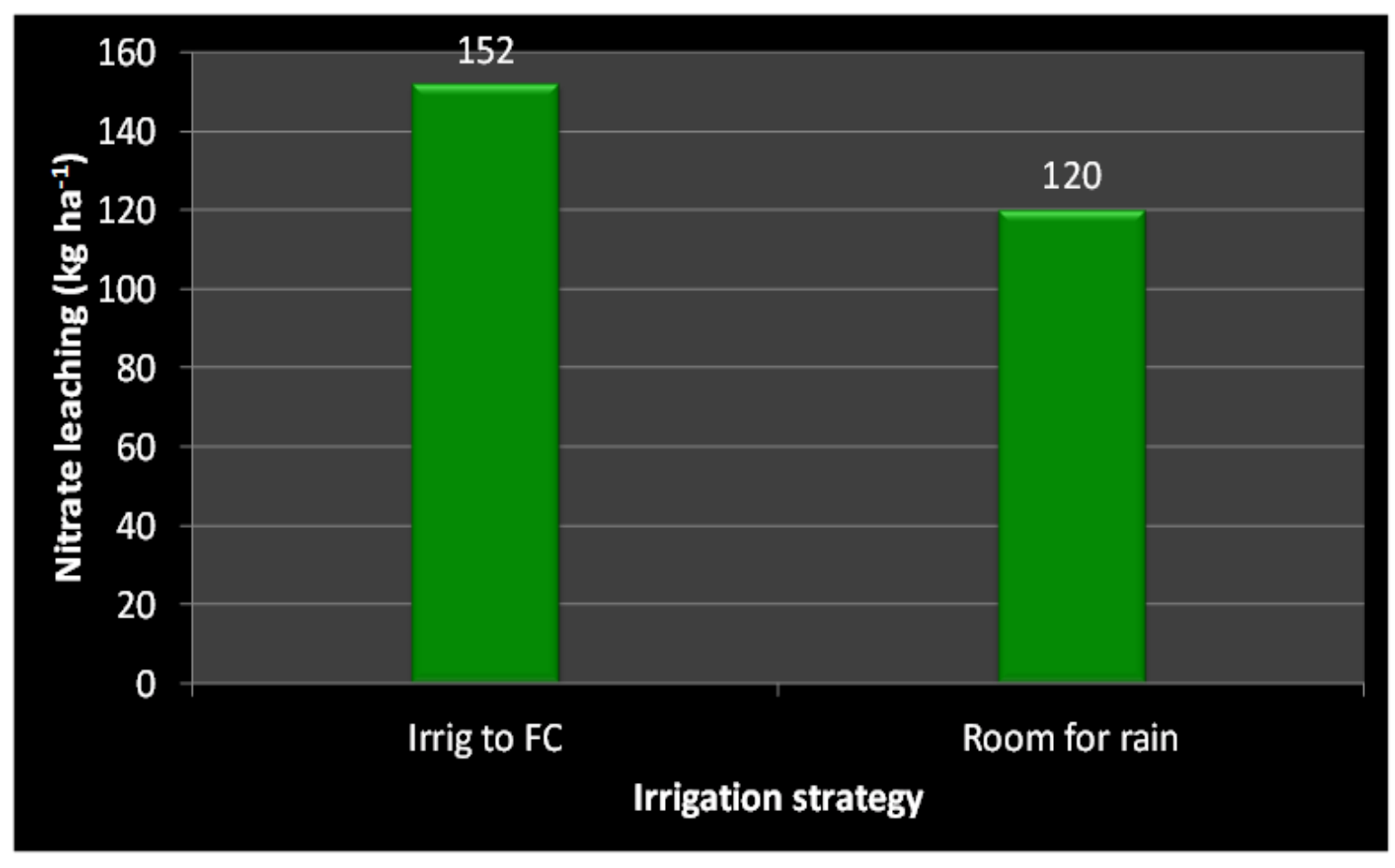

Fig. 10. Annual nitrate leaching from a clay loam soil treated with $10 \mathrm{Mg} \mathrm{ha}^{-1}$ sludge as influenced by irrigation strategy (irrigating to FC vs. leaving room for rain) (weather data from the 2007/08 growing season used for the simulation)

\subsubsection{Farming intensity implications on sludge application rates}

Intensive cropping systems improve land productivity by increasing the number of harvests per year as long as the water and nutrient demand of crops are satisfied. Hence, sludge guidelines which do not consider these complex matrices could either affect crop yield, the environment or both. For instance, maize forage yield was lower under an intensive irrigated maize-oat rotation $(15-30 \mathrm{Mg}$ $\left.\mathrm{ha}^{-1}\right)$ (Fig. 11) as opposed to irrigated maize alone (32.6 - 39.9 $\left.\mathrm{Mg} \mathrm{ha}^{-1}\right)$ (Fig. 6) in 24 out of 38 years when $10 \mathrm{Mg} \mathrm{ha}^{-1} \mathrm{yr}^{-1}$ sludge was applied to both cropping systems. This was mainly attributed to the deficiency of nutrients, especially N, under the irrigated maize-oat rotation (Fig. 12) as opposed to the irrigated maize alone (Fig. 7). 


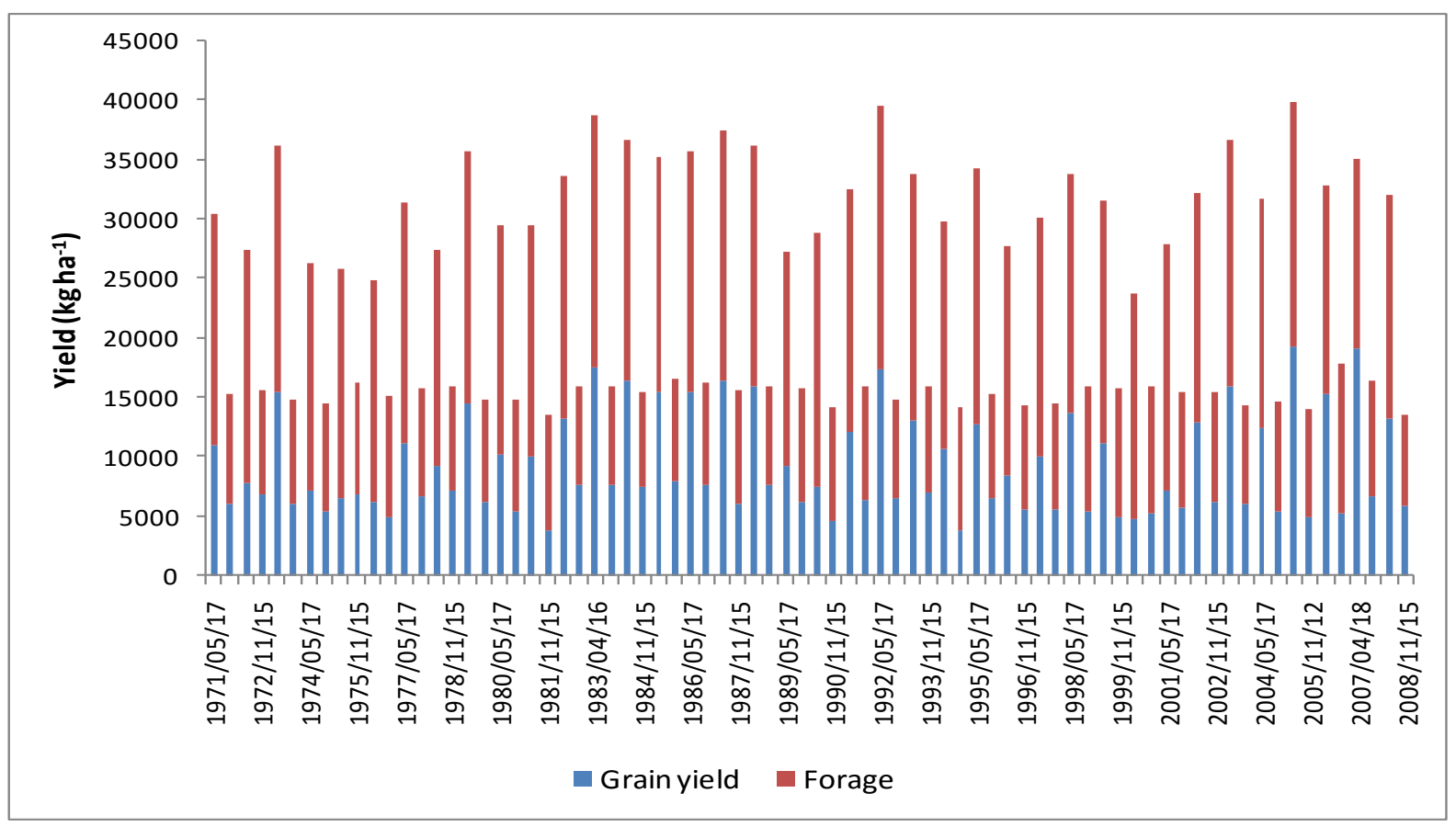

Fig.11. Simulated forage and grain yield of an irrigated maize (first season) -oats (second season) rotation planted to a clay loam soil treated with $10 \mathrm{Mg} \mathrm{ha}^{-1} \mathrm{yr}^{-1}$ sludge

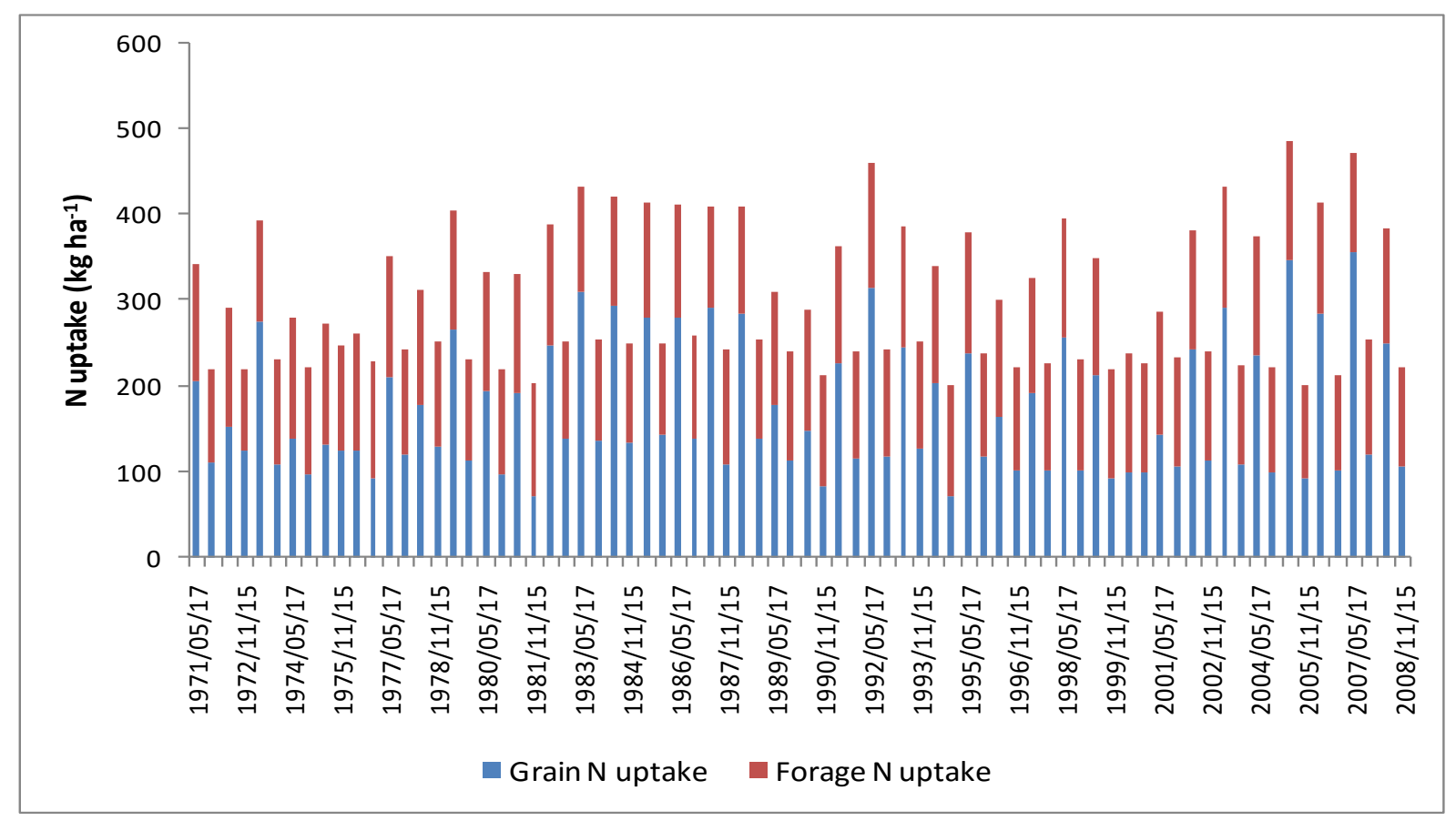

Fig.12. Simulated forage and grain $\mathrm{N}$ uptake of an irrigated maize (first season) -oats (second season) rotation planted to a clay loam soil treated with $10 \mathrm{Mg} \mathrm{ha}^{-1} \mathrm{yr}^{-1}$ sludge 
Model simulations show that nitrate leaching was higher under irrigated maize alone than an irrigated maize-oat rotation (Fig. 13). This was mainly due to extra $\mathrm{N}$ uptake by oats during the winter season from the rotation, minimising the potential for nitrate leaching, which could occur in early summer before active maize root development. Hence, sludge guidelines should consider dynamic reasoning support tools (models) that consider the intensity of the cropping system for optimal crop production with minimal environmental impacts.

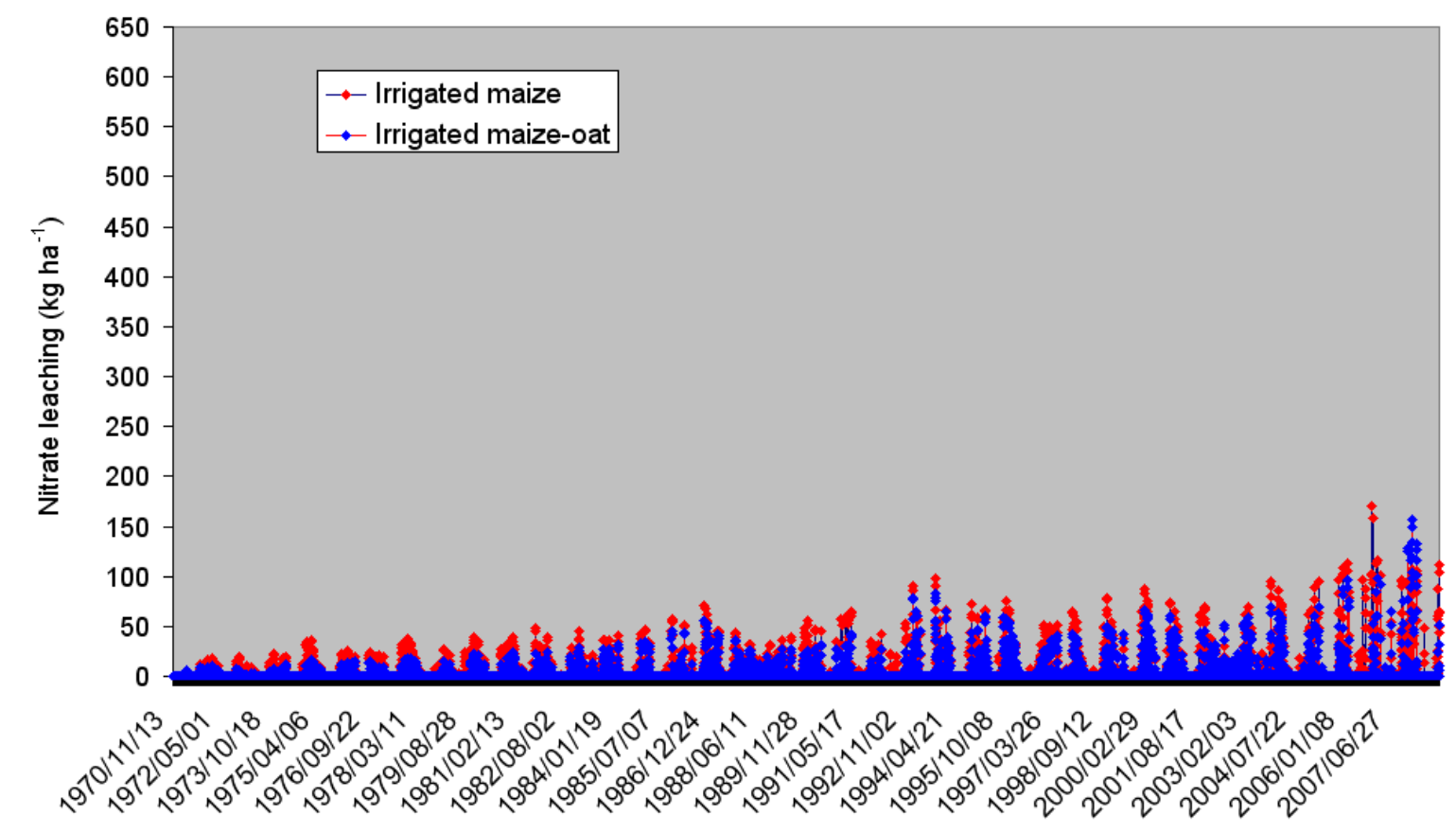

Fig.13. Simulated nitrate leaching from irrigated maize and irrigated maize-oat rotation planted to a clay loam soil treated with $10 \mathrm{Mg} \mathrm{ha}^{-1} \mathrm{yr}^{-1}$ sludge.

\section{Conclusions}

The SWB-Sci model was successfully calibrated for maize and oats. The model simulated both dry matter production and crop $\mathrm{N}$ uptake with acceptable accuracy. Model validation conducted using independent data sets also proved the accuracy of the model in simulating the above-mentioned 
variables under varying nutrient and water supply conditions, showing great promise as a reasoning support tool.

It was apparent from the long-term model simulation results that dryland farming systems with erratic and unpredictable rainfall conditions are prone to high environmental risk from nitrate leaching in the absence of site specific sludge application rate recommendations. According to the modelling scenario simulations, fixed annual $\mathrm{N}$ release rate recommendations, which are common in many countries of the world, often are not adjusted according to the availability of water and therefore are potentially vulnerable to nitrate leaching risks. Moreover, sludge application rate recommendations should take into account not only the residual soil inorganic $\mathrm{N}\left(\mathrm{NO}_{3}\right.$ and $\left.\mathrm{NH}_{4}\right)$, but also the contribution from soil organic matter, especially in soils which received sludge for decades. Under irrigated systems, most of the nitrate leaching took place when irrigation was applied to refill the soil profile back to field capacity. The strategy of leaving room for rain during irrigation, however, substantially reduced nitrate leaching losses and saved water without compromising crop yield. These model scenario simulation findings emphasize the role that dynamic reasoning support tools (models) could play in sludge application rate recommendations to optimize crop production and minimize environmental impacts.

\section{Acknowledgments}

We gratefully acknowledge financial support by the Water Research Commission of South Africa (WRC), East Rand Water Care Works (ERWAT), and Technology and Human Resources for Industry Programme (THRIP). We would like to thank ERWAT for providing the research site and numerous in-kind contributions. We are indebted to Mr. J.W. Wilken, Dr. Z. Godongwana, and Mr. Tseko from ERWAT for their distinct role in solving problems related to water, electricity, and sludge supplies. 
We also thank Mr. M. du Plessis from WRC and Dr H. Snyman from Golder Associates for their encouragement and motivation since the inception of the study.

\section{References}

Agehara, S., Warncke, D., 2005. Soil moisture and temperature effects on nitrogen release from organic nitrogen sources. Soil Sci. Soc. Am. J. 69, 1844-1855.

Allen, R.G., Pereira, L.S., Raes, D., Smith, M., 1998. Crop evapotranspiration - guidelines for computing crop water requirements. In FAO (eds.). FAO irrigation and drainage paper No. 56. Food and Agricultural Organization of the United Nations, Rome, Italy.

Annandale, J.G., Jovanovic, N.Z., Benadé, N., Tanner, P.D., 1999. Modelling the long-term effect of irrigation with gypsiferous water on soil and water resources. Agric. Ecosyst. Environ. 76, 109119.

Annandale, J.G., Campbell, G.S., Olivier, F.C., Jovanovic, N.Z., 2000. Predicting crop water uptake under full and deficit irrigation: An example using pea (Pisum sativum L. cv. Puget). Irrig. Sci. 19, $65-72$.

Annandale, J.G., Benadé N,, Van der Westhuizen A.J., Campbell G.S., 1996. The SWB (Soil Water Balance) irrigation scheduling model. Proc. of the Int. Conf. on Evapotranspiration and Irrigation Scheduling, San Antonio, Texas, USA. 944-949.

Annandale, J., Jovanovic, N., Campbell, G., Sautoy, N.D., Benade, N., 2003. A two-dimensional water balance model for micro-irrigated hedgerow tree crops. Irrig. Sci. 22, 157-170. 
Arbat, G., RosellÓ, A., Domingo Olivé, .F., Puig-Bargués, J., González Linás,.E., Duran-Ros, M. Pujol, J., Ramírez de Cartagena, F., 2013. Soil water and nitrate distribution under drip irrigated corn receiving pig slurry. Agric. Water Manage. 120, 11-22.

Beek, J., Frissel, M.J., 1973. Simulation of Nitrogen Behaviour in Soils. Centre for Agricultural Publishing and Documentation, Wageningen.

Beletse, Y., Annandale, J., Steyn, J., Hall, I., Aken, M., 2008. Can crops be irrigated with sodium bicarbonate rich CBM deep aquifer water? Theoretical and field evaluation. Ecol. Eng. 33, 26-36.

Bergström, L. Johnsson, H., Torstensson, G., 1991. Simulation of soil nitrogen dynamics using the SOILN model. Fert. Res. 27, 181-188.

Binder, D.L., Dobermann, A., Sander, D.H., Cassman, K.G., 2002. Biosolids as nitrogen source for irrigated maize and rainfed sorghum. Soil Sci. Soc. Am. J. 66, 531-543.

Blum, J., Melfi, A.J., Montes, C.R., Gomes, T.M., 2013. Nitrogen and phosphorus leaching in a tropical Brazilian soil cropped with sugarcane and irrigated with treated sewage effluent. Agric. Water Manage. 117, 115-122.

Bouniols, A., Cabelguenne, M., Jones, C.A., Chalamet, A.,Charpenteau, J.L., Marty, J.R., 1991. Simulation of soybean nitrogen nutrition for a silty clay soil in southern France. Field Crop Res. 26, 19-34.

Boyle, M., Paul, E., 1989. Carbon and nitrogen mineralization kinetics in soil previously amended with sewage sludge. Soil Sci. Soc. Am. J. 53, 99-103.

Cameira, M.R., Fernando, R.M., Pereira, L.S., 2003. Monitoring water and $\mathrm{NO}_{3}-\mathrm{N}$ in irrigated maize fields in the Sorraia watershed, Portugal. Agric. Water Manage. 60, 199-216. 
Corwin, D.L., Waggoner, B.L., Rhoades, J.D., 1991. A Functional Model of Solute Transport that Accounts for Bypass. J. Environ. Qual. 20, 647-58.

De Jager, J., 1994. Accuracy of vegetation evaporation ratio formulae for estimating final wheat yield. Water SA 20, 307-314.

Du, W., Jiang, J., Gong, C., 2012. Primary research on agricultural effect of sludge-impact of sludge application on crop seeds germination and seedling growth. Procedia Environ. Sci. 16, 340345.

Dutt G.R., Shaffer, M.J., Moore, W.J., 1972. Computer simulation model of dynamic biophysiochemical processes in soils. Tech. Bulletin 196. Arizona Agricultural Experiment Station.

Esteller, M.V., Martínez-Valdés, H., Garrido, S., Uribe, Q., 2009. Nitrate and phosphate leaching in a Phaeozem soil treated with biosolids, composted biosolids and inorganic fertilizers. Waste Manage. 29, 1936-1944.

Fierer, N., Schimel, J., Holden, P.A., 2003. Influence of drying-rewetting frequency on soil bacterial community structure. Microbial Ecol. 45, 63-71.

Garau, M.A., Felipo, M.T., Ruiz de Villa, C., 1986. Nitrogen mineralization of sewage sludges in soils. J. Environ. Qual. 15, 225-228.

Godwin, D. C., Jones, A.C., 1991. Nitrogen Dynamics in Soil Plant Systems. In Modeling Plant and Soil Systems, eds. J. Hanks \& J. T. Ritchie. Amer. Soc. Agron., 31, 297-302.

Guntiñas, M.E., Leirós, M.C., Trasar-Cepeda, C., Gil-Sotres, F., 2012. Effects of moisture and temperature on net soil nitrogen mineralization: A laboratory study. Eur. J. Soil Biol. 48, 73-80. 
Halverson, L.J., Jones, T.M., Firestone, M.K., 2000. Release of intracellular solutes by four soil bacteria exposed to dilution stress. Soil Sci. Soc. Am. J. 64, 1630-1637.

Heimann, M., Reichstein, M., 2008. Terresterial ecosystem carbon dynamics and climate feedbacks. Nature 451, 289-292.

Janssen, B., 1996. Nitrogen mineralization in relation to C: $\mathrm{N}$ ratio and decomposability of organic materials. Plant Soil 181, 39-45.

Jovanovic, N., Annandale, J., Bennie, A.T.P. 2002. Calibration and validation of the SWB irrigation scheduling model for Soyabean [Glycine max. (L.) Merr., indeterminate cv. Wayne]. S. Afr. J. Plant Soil 19, 165-172.

Jovanovic, N., Annandale, J., Mhlauli, N., 1999. Field water balance and SWB parameter determination of six winter vegetable species. Water SA 25, 191-196.

Kelley W.D., Martens D.C., Reneau R.B., Simpson, T.W. 1984. Agricultural use of sewage sludge: A literature review. Virginia Water Resource Research Centre, Virginia Polytechnic Institute and State University, Blackburg.

Kropff, M.J. Bouma, J., Jones, J.W., 2001. Systems approaches for the design of sustainable agroecosystems. Agric. systems 70, 369-393.

Leiros, M., Trasar-Cepeda, C., Seoane, S., Gil-Sotres, F., 1999. Dependence of mineralization of soil organic matter on temperature and moisture. Soil Biol. Biochem. 31, 327-335.

Mian, I.A., Riaz, M., Cresser, M.S., 2008. What controls the nitrate flush when air dried soils are rewetted? Chem. Ecol. 24, 259-267. 
Seleiman, M.F., Santanen, A., Stoddard, F.L., Mäkelä, P., 2012. Feedstock quality and growth of bioenergy crops fertilized with sewage sludge. Chemosphere 89, 1211-1217.

Shaffer, M.J., Ma, L., Hansen, S., 2001. Modeling Carbon and Nitrogen Dynamics for Soil Management. Lewis Publishers, Boca Raton, FL.

Snyman, H., Herselman, J., 2006. Guidelines for the utilisation and disposal of wastewater sludge: Volume 1: Selection of management options. WRC Report No.TT 261/06, Water Research Commission, Pretoria, South Africa.

Soil Classification Working Group, 1991. Soil Classification: A Taxonomic System for South Africa. The Department of Agricultural Development, Pretoria.

Stirzaker, R.J., 2003. When to turn the water off: Scheduling micro-irrigation with a wetting front detector. Irrig. Sci. 22, 177-185.

Stirzaker, R.J., Hutchinson, P.A., 2005. Irrigation controlled by a wetting front detector: Field evaluation under sprinkler irrigation. Aust. J. Soil Res. 43, 935-943.

Stöckle, C.O., Campbell, G. S., 1989. Simulation of Crop Response to Water and Nitrogen: An Example Using Spring Wheat. Trans. of the ASAE, 32, 66-68.

Stöckle, C.O., Martin, S., Campbell, G.S., 1994. CropSyst, a cropping systems model: water/nitrogen budgets and cropyield. Agric. Syst. 46, 335-359.

Stöckle, C.O., Donatelli, M., Nelson, R., 2003. CropSyst, a cropping systems simulation model. Eur. J. Agron. 18, 289-307.

Tesfamariam, E.H., 2009. Sustainable use of sewage sludge as a source of nitrogen and phosphorus in cropping systems. Ph.D. Thesis, University of Pretoria, South Africa. 
Tesfamariam, E.H., Annandale, J.G., Steyn, J.M., Stirzaker, R.J., 2009. Exporting large volumes of municipal sewage sludge through turfgrass sod production. J. Environ. Qual. 38, 1320-1328.

van der Laan, M. 2009. Development, testing and application of a crop nitrogen and phosphorus model to investigate leaching losses at the local scale. Ph.D. Thesis, University of Pretoria, South Africa.

Yague, M.R., Quilez, D., 2010. Response of maize yield, nitrate leaching, and soil nitrogen to pig slurry combined with mineral nitrogen. J. Environ. Qual. 39, 686-696. 